\title{
Oligomictic alluvial aggregates: petro-mineralogical and geochemical evaluation of sandy gravel formations on the middle course of the Danube (Hungary)
}

\author{
V. Szilágyi ${ }^{1}$ (I) K. Gméling ${ }^{1} \cdot$ S. Józsa ${ }^{2} \cdot$ I. Harsányi $^{1} \cdot$ L. Szentmiklósi $^{1}$
}

Received: 17 July 2020 / Accepted: 3 May 2021 / Published online: 1 June 2021

(C) The Author(s) 2021

\begin{abstract}
This paper evaluates the applicability of Hungarian oligomictic alluvial gravel formations at two sections of the Danube river for construction use. The classification of these aggregates is more challenging than monomictic rock aggregates due to their heterogeneous nature. Multi-source clastic sediments cannot be characterized by single values of physical properties but only a distribution, and they are generally less predictable than monomictic materials. The possible applications in concrete manufacturing were evaluated by complex macro-microscopic petrographic, heavy mineral and nuclear analytical geochemical investigations. The two regions falling on the middle course of the Danube have similar sandy gravel formations, applicable as aggregates for conventional and unconventional concrete building purposes or road construction. Their utilization in open-air constructions might be problematic due to their probable alkali-silica reactivity.
\end{abstract}

Keywords Multi-source aggregates $\cdot$ Petrographic evaluation $\cdot$ Heavy minerals $\cdot$ Nuclear analytical techniques $\cdot$ Prompt gamma activation analysis $\cdot$ Neutron activation analysis

\section{Introduction}

Being abundant at the surface or near-surface localities, clastic sediments are a common subject of raw material exploitation worldwide. Sandy gravel formations are fundamental raw material sources of the construction industry, especially in concrete manufacturing as aggregates. The applicability of these clastic sediments is determined by physical characteristics that affect their durability (against freeze-thaw processes, chemical agents, heat, mechanical stress). Concretes for different purposes require raw materials with specific properties (e.g. high compressive strength for basement constructions, ionizing-radiation resistivity for biological shielding materials) (e.g. Alexander and Mindess 2005).

To qualify clastic raw materials for concrete industrial purposes, international standards (ASTM C 295 2019; DIN

V. Szilágyi

szilagyi.veronika@energia.mta.hu

1 Centre for Energy Research, Nuclear Analysis and Radiography Department, Budapest, Hungary

2 Department of Petrography and Geochemistry, Eötvös Loránd University, Budapest, Hungary
EN 932 1996; DIN EN 933 2015) have been established, applying conventional mineralogical and petrographic methods. In addition, granulometry and grain shape analysis are also fundamental properties to be determined and described in standards (ASTM D 4791 (2019) for coarse aggregate; CRD-C-120 (1994) for fine aggregate; ASTM C 295 (2019) and ASTM D 3398 (2000) for shape analysis).

Aggregates have to meet numerous specifications to become suitable to concrete production (Berubé 2001). One of them is the characterization of the grain population (e.g. size distribution, gradation, grain shape, surface texture). Another aspect is the overall composition (mineralogical and/or chemical) which specifies the presence of the harmful substances in the aggregate (e.g. clay minerals, organic matter, micas, iron- and manganese-oxide staining, finegrained siliceous material, alteration or weathering in the form of incrustation on grains). Specific characteristics can be set for the surface moisture or water content, absorptivity, specific gravity, bulk density, or void content. Such properties ultimately determine the mechanical performance (resistance against fragmentation, abrasion or polishing), durability (resistance against environmental conditions) and chemical stability (resistance against deleterious chemical reactions including alkali-aggregate reactivity) of the 
concrete. Durability and mechanical resistivity are defined by European Standard test methods (e.g. EN 1097-1 2003; EN 1097-2 2006; EN 1097-9 2005; Erichsen et al. 2011) and affected by initial weathering state of the aggregates and environmental (i.e. climatic and anthropogenic) conditions (e.g. EN 1367-1 2007; EN 1367-2 2010; Šachlová et al. 2016, 2017; Czinder and Török 2019).

Chemical stability belongs to one of the most desirable aspects of aggregates when used as fillers in concrete. From the range of different deleterious chemical reactions, alkali silica reactivity of aggregates is among the most widely studied (Fernandes and Broekmans 2013). This chemical reaction takes place between the alkalis of the pore solutions (cement paste) and certain forms of silica in the aggregates inside the concrete (Stanton 1940; Swamy 1992; Dron and Brivot 1992, 1993; Fournier and Bérubé 2000). Volumetric expansion due to the formation of alkali silica gel presents a harmful process influencing the integrity of concrete structure. Prediction of chemical stability of aggregates in concrete is preferentially done by detailed petrographic examination (e.g. West 1994; Ramachandran and Beaudoin 2000; Šachlová et al. 2016, 2017; Kuchařová et al. 2016; Ahmad et al. 2018) or by wellestablished physical tests (e.g. ASTM C 1260 2014, RILEM AAR-1,-2 2016). Furthermore, ionizing radiations can induce or accelerate the deterioration of concrete via alkali-silica reaction even if the aggregates were inert to alkali before the irradiation (Ichikawa and Koizumi 2002, 2007). Such damage mechanisms in concrete may be more pronounced in an environment with elevated temperature and humidity. In Hungary, ASR-susceptible rocks are amorphous to weakly crystalline silica containing (volcanic rocks) or deformed quartz containing rocks (quartzite, sand, gravel, metavolcanites) (Fernandes et al. 2018).

There is an elaborate correlation between the petrographic and technical properties of aggregates (Johansson et al. 2015). Multivariate statistical analysis revealed that the mean grain size (on average and for certain mineral grains), the grain-size distribution, the sensitive-mineral content (e.g. mica) and the frequency of microcracks are the main factors that influence the technical properties. Since aggregates are exposed to intensive mechanical, physical and chemical stresses during the service life of the concrete, these clastic materials have to be resistant. All abovementioned properties and requirements of aggregates are fundamentally determined by the mineralogical composition, the fabric and the structure of the material. Thus, the petrographic investigation of aggregates provides a solid basis for the assessment of their performances in a concrete structure.

Polymictic alluvial clastic aggregates differ from monomictic rock aggregates exploited in quarries for construction purposes. That justifies a comprehensive analysis with a special emphasis on the petrographic-geochemical examinations. The study of pebble lithology and the composition of fine particles and heavy minerals are traditional methods in provenance analysis (Dickinson 1985; Pettijohn et al. 1987; Lihou and Mange-Rajetzky 1996). The size, lithology and maturity of the sediment (i.e. ultimate survival of various lithologies) are determined by the lithology of the source area, the rate and distance of transport and the degree of recycling and weathering. Local outcrops, tributaries to the mainstream and re-deposition from older strata may contribute to the clast population and the mixing along the fluvial course, resulting in multi-cycle clast populations (e.g. Lindsey et al. 2007).

Although potential of freshly exploited monomictic (e.g. andesite) aggregates is intensively investigated (Török and Czinder 2017; Czinder and Török 2019, 2020), there are several extended alluvial sandy gravel formations in Hungary that are dominantly exploited for construction purposes. This phenomenon is characteristically different from the Central European practice and is due to the geological-geographic situation of Hungary being a great sedimentary basin of Danube. This study focuses on two regions of the middle course of the Danube (the main river of the country and the Carpathian Basin): the NW Hungarian and the Mid-Danubian regions. The detailed mineralogical-petrographic and geochemical characterization of different fractions of the clastic sediments provides a solid scientific evidence to classify them according to their industrial applicability. This paper aims to provide a detailed geological description of sand-to-gravel fractions of the NW Hungarian and the Mid-Danubian regions by microscopic petrographic, heavy mineral and bulk geochemical investigations.

Until now, such systematic and comprehensive information was not available concerning Hungarian gravel mining sites. Our investigation does not aim to make a provenance study but to compile the micro-scale characteristics that are relevant to the overall physical properties of the aggregates. Using these data, the applicability of clastic sediments for construction becomes predictable.

\section{Materials and geological setting}

The Danube enters the Carpathian Basin at Dévény (Devin) tight where the middle river course type with a high sedimentdeposition rate is typical. The geology of the catchment area of the river is varied; thus, varied petrographic composition of the clastic sediments can be expected parallel with high ratio of coarse-grained fractions and moderate (re)working of the grains. In addition to the bulk transported by the Danube from the west of Dévény, the average petrographic composition has been affected by the tributaries inside the basin, as well as the local geology. For instance, in the central part of the Carpathian Basin, the alluvial sediments are supplemented by Miocene volcanic input from the close mountainous area of Visegrád-Börzsöny (Karátson et al. 2000, 2007).

At the NW Hungarian region, the Danube enters from the elevated mountainous background (breaking through the 
Hainburg Block and the Little Carpathians) to a depressing/ subsiding basin where the river deposits most of its sediments, and especially its coarse-grained sediments, forming a huge alluvial cone (Franyó 1967; Hajósy et al. 1993). The depression is filled with over $2000 \mathrm{~m}$ of Pannonian marine mainly sandy-silty and 100-250 m (max. $700 \mathrm{~m}$ ) of Quaternary fluvial sandy-gravelly sediments. The Quaternary sedimentation was determined by the tectonic activity of the Rába lineament which divided the homogeneous Pleistocene alluvial cone into two separate regions: a continuously depressing basin and an elevated terrace. The Holocene alluvial sedimentation is partly driven also by the transportation of smaller rivers (Rába, Marcal, Rábca, Répce) which — just like the relevant part of the Danube river - provided a low energy depositional environment (slow and shallow river beds, abandoned meanders). The NW Hungarian region of the Danube is characterized both by middle course type meandering beds (MosonDanube) and lower course type braided channels (Danube major bed). The sedimentation is mainly happened in the major braided channel, while the minor meandering channels helped the lateral distribution of the sediments. The Holocene gravelly formations show decreasing average grain size from west to east (on a $50 \mathrm{~km}$ long distance it can decrease from 50-70 mm to 25-35 mm) (Szádeczky-Kardoss 1938; Károlyi 1957; Pécsi 1962). Although the gravelly sediments are fauna-free which makes the litho-chronostratigraphic classification difficult, they are divided into three main members (separated by erosional and tectonic discordances) (Jaskó 1990). The upper member is an Upper Pleistocene-Holocene gravel, gravelly sand formation (with subordinate fine sediments on its top) of the Marcal, Rába and Répce rivers deposited in shallow depressions (10-50 m thickness). The lower member is limited to tectonic trenches but even with $100 \mathrm{~m}$ thickness. The cross-bedded sand- to siltstone member is a fluviatile fine-grained formation forming the footwall of the lower member (its thickness is some hundreds of meters in the center of the basin while it is thin on the rims). The upper member can be divided into the silty clayey materials of the Upper Holocene low floodplain, sand and sandy gravel of the Lower Holocene high floodplain and the sandy gravel sediments of the Upper Pleistocene terrace (Kaiser et al. 1998; Jánossy and Krolopp 1994).

At the Mid-Danubian region, the first (Upper PleistoceneHolocene) and second ( $a$ and $b$, Upper Pleistocene) terraces of the Danube are extended (Burján 2002). The sediments (dominantly $12-16-\mathrm{mm}$-sized fine gravel) of the terraces $2 \mathrm{a}$ and $2 \mathrm{~b}$ are well-sorted, characterized by distribution curves with two maxima ( 0.4 and $8-16 \mathrm{~mm}$ peak values). Sediments of terrace $2 \mathrm{~b}$ (medium-coarse-grained sand with gravels) are slightly coarser than those of terrace 2a (fine-medium-coarse-grained sand with gravels). Sediments of the first terrace are located at the flood plain of the Danube (20-25 km wide around the riverbed in this region) (Molnár 1995). Its basement is Pannonian clay-sand formation (Bulla 1941; Pécsi 1959; Erdélyi 1967; Kriván 1960; Sümeghy 1952, 1953). The first terrace sediments are well-sorted and two maxima distribution curves (0.4 and 32-40 mm maximum values) are typical. According to previous research, Danube clastic sediments on the Hungarian course have well-rounded and medium spherical shapes (Pécsiné Donát 1958).

Our study focuses on two selected sections of the river course (Fig. 1). The NW Hungarian region involves the surroundings of Gyôr with four selected gravel pits (abbreviated as NW-1-4). The Mid-Danubian region is situated to the south from Budapest with four mining sites (abbreviated as MD1-4). All pits operate with shore excavation or bed dredging (Fig. 2). The gravels are washed with the lake water and assorted into four grain-size fractions.
Fig. 1 Simplified geological map of the two investigated regions with the differentiation of Holocene floodplain levels and Pleistocene low-high terraces (or older sediments). The positions of the sampled openair sandy gravel quarries in the NW Hungarian and the MidDanubian regions are indicated with black dots

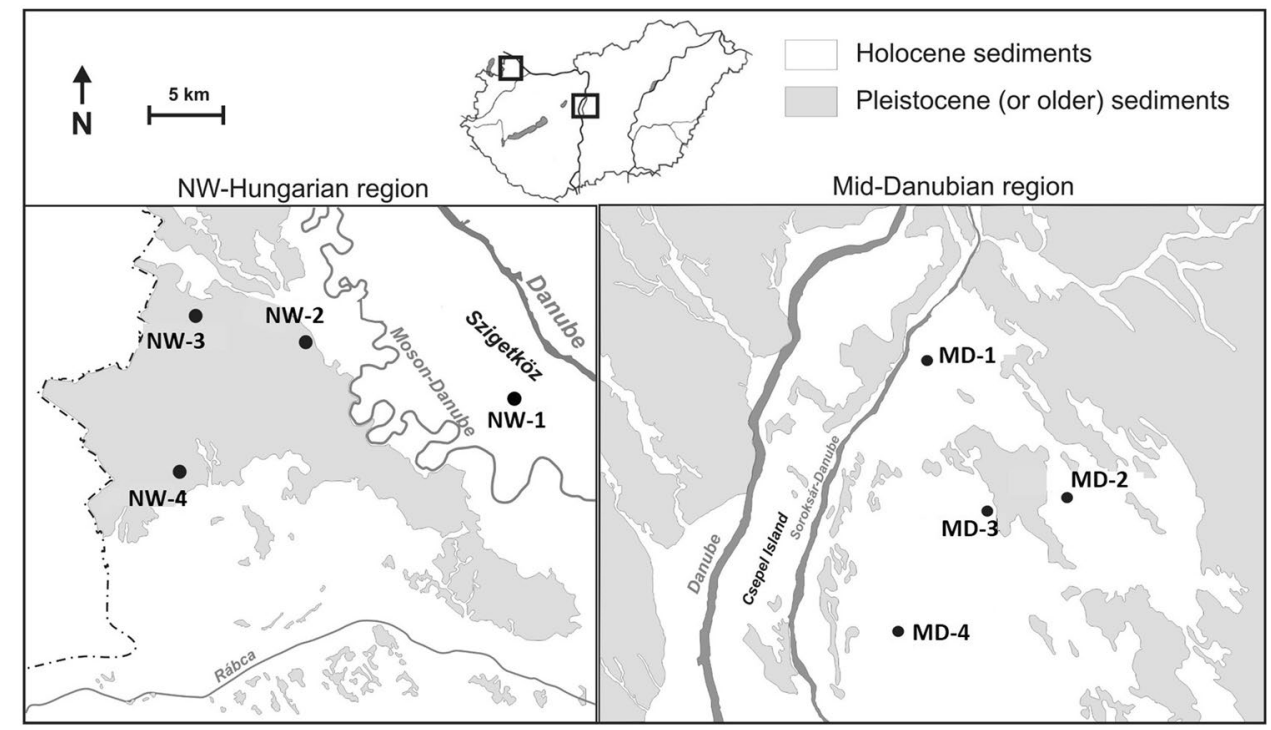




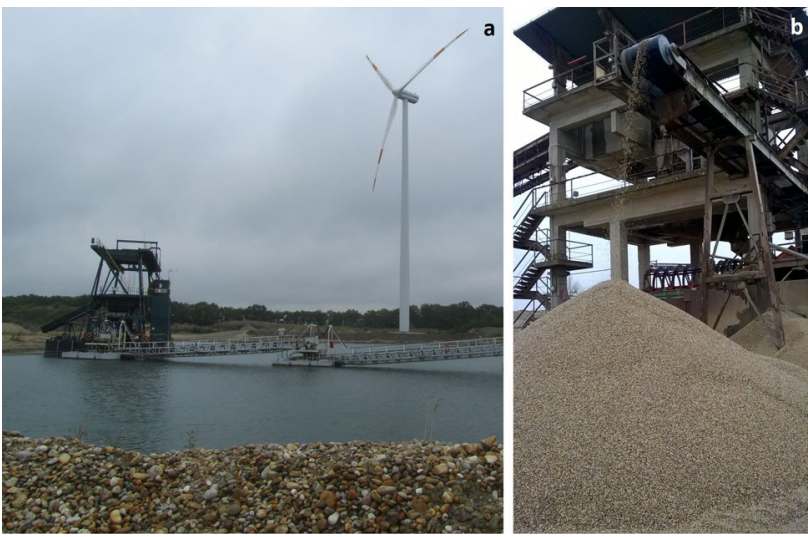

Fig. 2 Gravel pits operating with (a) bed dredging and (b) assorting system

From every selected quarry four sorted (particle size $0-4$, $4-8,8-16,16-32 \mathrm{~mm}$ ) and washed samples were collected. The sampling was made with care, and after homogenization, the representative portions were taken from the whole with the halving method.

\section{Methods}

Macroscopic, microscopic and heavy mineral studies were made on the different grain fractions. Variability in the quality and nature of individual outcrops were established using a combination of petrographic techniques on different scales. From all the localities, traditional macroscopic gravel petrography was done on the 4-8-, 8-16- and 16-32-mm fractions classifying av. 200 pebbles by fractions (Fig. 3). In addition, the 2-4-mm fraction was selected for fine-grained pebble examinations (FPE; Bradák et al. 2014) which
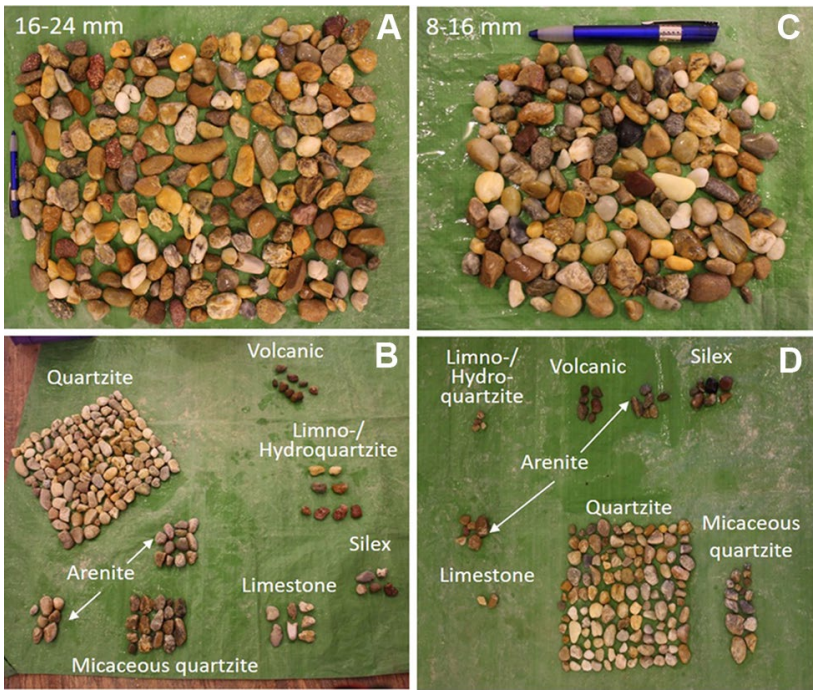

Fig. 3 Macroscopic petrographic examination and documentation of the coarse pebble (MD-1 16-24 mm (a-b) and 8-16 mm (c-d)) fractions involved the modal composition analysis in petrographic thin sections (embedded in cement, instead of epoxy) containing more than 300 grains per sample. Microscopic petrographic investigations were done on a Zeiss petrographic polarizing microscope. The quantification was based on the grain counting method. As the sieved gravel fractions have uniform grain-size distributions, our results produced by grain counting method are corresponding to the results gained by the conventional point counting method.

Another aspect of microscopic petrographic investigations was the evaluation of potentially alkali-silica reactive (ASR) aggregates. The chemical process is described in the literature (Stanton 1940; Swamy 1992; Dron and Brivot 1992, 1993; Fournier and Bérubé 2000), and in addition to the physical and chemical tests, the petrographic examination of aggregates is a basic method to predict the potential reactivity (e.g. West 1994; Ramachandran and Beaudoin 2000; Ahmad et al. 2018; Šachlová et al. 2016, 2017). In the Hungarian Danube sediments, being silicate-based lithological assemblages, ASR-sensitive forms of silica (micro- or cryptocrystalline quartz, submicroscopic or disordered quartz, strained quartz, opal, chalcedony, tridymite, cristobalite, devitrified glass) are determined and quantified, since those can be harmful in the concrete mixture already in small amounts (e.g. 2 w\% opal) (French 1991; Beck et al. 2000; Danielsen and Nebdal Svendsen 1991; Anastasio et al. 2016). In this study, we followed the recommendations of Fernandes et al. (2016); the undulatory extinction angle method proposed by Dolar-Mantuani (1983), West (1991, 1994) and Ramos et al. (2016); and the microcryptocrystalline silica content determination emphasized by Andersen and Thaulow (1989) and Ramachandran and Beaudoin (2000).

There were eight samples (one sample per quarry) selected for heavy mineral investigations. The specimens were made of the washed 0-4-mm fraction by subsequent drying (on room temperature), mass weighing, dry-wet-dry sieving $(63,125$ and $250 \mu \mathrm{m}$ sieve sizes), mass weighing of the four fractions, selection of fractions $63-125 \mu \mathrm{m}$ and $125-250 \mu \mathrm{m}$, concentrating the heavy mineral fraction in the two size-fractions by a heavy liquid (bromoform) and repeated rinsing with alcohol, separate mass weighting of heavy and light fractions in both size ranges, and preparation of polished grain section of the two heavy mineral fractions (embedded in synthetic resin, planar burnishing to uncover the complete cross-section of the grains). The analysis involved the qualitative and quantitative determination of the mineral species and their main characteristics by a Nikon OPTIPHOT2-POL polarizing microscope. The photo documentation was done with a Nikon DS Fil camera and the NIS Elements software. The quantitative determination was done with the Fleet grain counting method (Fleet 1926; Galehouse 1969) which gives a number percentage, but 
- because of definite grain size - these data can be used as area or volume percentages as well (Galehouse 1969).

The elemental compositions of samples (four fractions from each site) were determined by a combination of nuclear analytical techniques. Prompt-gamma (PGAA) and instrumental neutron activation analysis (NAA) were performed at the Centre for Energy Research, Budapest (see the method-description in Szilágyi et al. 2019). The set of elements obtained by these two methods is comparable for some elements (these can be used as an internal quality assurance indicator) and complementary for many other elements. Since the neutrons can penetrate deeply into the sample, the analytical information is highly representative to the bulk of the materials. Peak identification and quantitative analyses of both methods are performed using the $k_{0}$ method (De Corte 1987; Révay 2009; Firestone et al. 2014; Molnár 2004). The major-minor element compositions ( $\mathrm{Si}, \mathrm{Ti}$, $\mathrm{Al}, \mathrm{Fe}, \mathrm{Mn}, \mathrm{Mg}, \mathrm{Ca}, \mathrm{Na}, \mathrm{K}, \mathrm{H}$ ) of the sandy gravel samples have been determined by PGAA. In silicate matrices, some additional important trace elements (B, Cl, Sc, V, Cr, Co, Nd, Sm and Gd) also can be detected by PGAA. The upgraded Budapest PGAA facility was technically described by Szentmiklósi et al. (2010) in detail. During the analysis, the whole sample (in solid or powdered form) is irradiated by cold neutrons in an external beam (thermal equivalent flux of $1.2 \times 10^{8} \mathrm{~cm}^{-2} \mathrm{~s}^{-1}, 24 \mathrm{~mm}^{2}$ to $1 \mathrm{~cm}^{2}$ beam spot size). During the neutron irradiation, the induced characteristic gamma radiation is detected with a HighPurity Germanium Detector with a Bismuth-Germanate Scintillator active background reduction system (HPGe-BGO) placed next to the beamline. The trace element compositions (As, Ba, $\mathrm{Br}, \mathrm{Ca}, \mathrm{Ce}, \mathrm{Co}, \mathrm{Cr}, \mathrm{Cs}, \mathrm{Eu}, \mathrm{Fe}, \mathrm{Hf}, \mathrm{K}, \mathrm{La}, \mathrm{Na}, \mathrm{Nd}, \mathrm{Rb}, \mathrm{Sb}, \mathrm{Sc}$, $\mathrm{Sm}, \mathrm{Sr}, \mathrm{Ta}, \mathrm{Tb}, \mathrm{Th}, \mathrm{U}, \mathrm{W}, \mathrm{Yb}, \mathrm{Zn}, \mathrm{Zr}$ ) of sandy gravels have been measured by NAA. The features of the Budapest NAA facility were described by Szentmiklósi et al. (2016). With this technique, we irradiate the powdered samples with neutrons in the research reactor's active zone (thermal neutron flux of 3.0 $\times 10^{13} \mathrm{~cm}^{-2} \mathrm{~s}^{-1}$ ), and the gamma rays from the decay of shortand long-lived radionuclides are observed through a multi-step detection procedure (4-5 and 20-30 days after irradiation) using well-shielded HPGe detectors.

\section{Results}

\section{Macroscopic pebble petrography of the coarser fractions}

The general results of pebble petrography (of the 16-24-mm, 8-16-mm and 4-8-mm fractions) are presented in Figs. 4 and 5. Concerning their compositions, the gravels can be classified as oligomictic (quartzose) and subordinately polymict (two cases: NW-2 8-16 mm, NW-4 8-16 mm). Quartz pebbles predominate but those are usually below $70 \%$. Comparing the two main regions, it is a fact that limestone is more common among the sedimentary rock types in the NW Hungarian region.
Sediments of the Mid-Danubian region contain several quartz varieties. Yellow and brownish quartzite are the main types, the white type is less common, whereas dark to light grey ones occur subordinately. Quartz and mica (mainly muscovite) containing (metamorphic or metagranitoid) rock fragments were observed in almost all quarries (micaceous quartzite, phyllite, gneiss of Palaeozoic crystalline formations from the Garam river catchment area/Bohemian Massif; Bradák et al. 2014) (7.0-12.5\%). Further rock types, such as volcanites, silex, siliciclastites, limno-/hydroquartzite or limestone additionally, are present $(22.0-31.5 \%)$. Volcanites are grey-black-red andesite clasts with feldspar and amphibole phenocrysts and are originated from the Visegrád and Börzsöny Mts. (Karátson et al. 2000, 2007). Siliceous sedimentary rocks are grey-black sandstone, quartzose sandstone and siltstone or rarely marl-claystone (Szeberényi et al. 2014). Quartz arenite pebbles are remarkable in MD-3 8-16-mm and 4-8-mm fractions (15\%). Limestones are white-pale yellow micritic-sparitic inhomogeneous and homogenous textured, fossil-free rocks probably of Mesozoic or Miocene age (Bradák et al. 2014).

Clastic fractions of the NW Hungarian region are also predominated by quartz varieties. White to yellow quartzite is the main type, whereas dark to light grey and brown ones are subordinate. Metamorphic or metagranitoid rock fragments (quartz and mica composition; e.g. micaceous quartzite, phyllite, gneiss) were recognized in all quarries (11.0-27.9\%) and possibly could derive from the crystalline formations of the Bohemian Massif (Bradák et al. 2014). Other rock types (volcanites, silex, siliciclastites, limno-/hydroquartzite, limestone) are additionally present (12.0-30.4\%). Relevantly higher limestone content (6.5-11.5\%) at NW-1 and NW-2 could be observed. Siliciclastites are red-yellow sandstones, light-colored calcareous sandstones (Neogenic of the Leitha Mts.), quartz arenites and green-grey-black siltstones (Mesozoic flysch and molasse sediments of the $\mathrm{N}$, E or Central Alps). Limestones are grey-greyish yellow fine micritic fossil-free rocks of Mesozoic (N, E or Central Alps) or Neogene age (Leitha Mts.) (Szeberényi et al. 2014).

The petrography of pebbles reflects relatively high maturity. The provenance was significantly influenced by the basement and the river catchment area composition. The absolute dominance of quartz or quartz dominated metamorphic-metagranitoid rock fragments indicates the provenance from weathered crystalline rocks (of the Alps/Bohemian Massif) and the longer sediment transportation path. The minor role of sedimentary rocks (e.g. silex, siliciclastic rocks, limestone) and volcanites is dictated by the local geology (influence of smaller river input). 


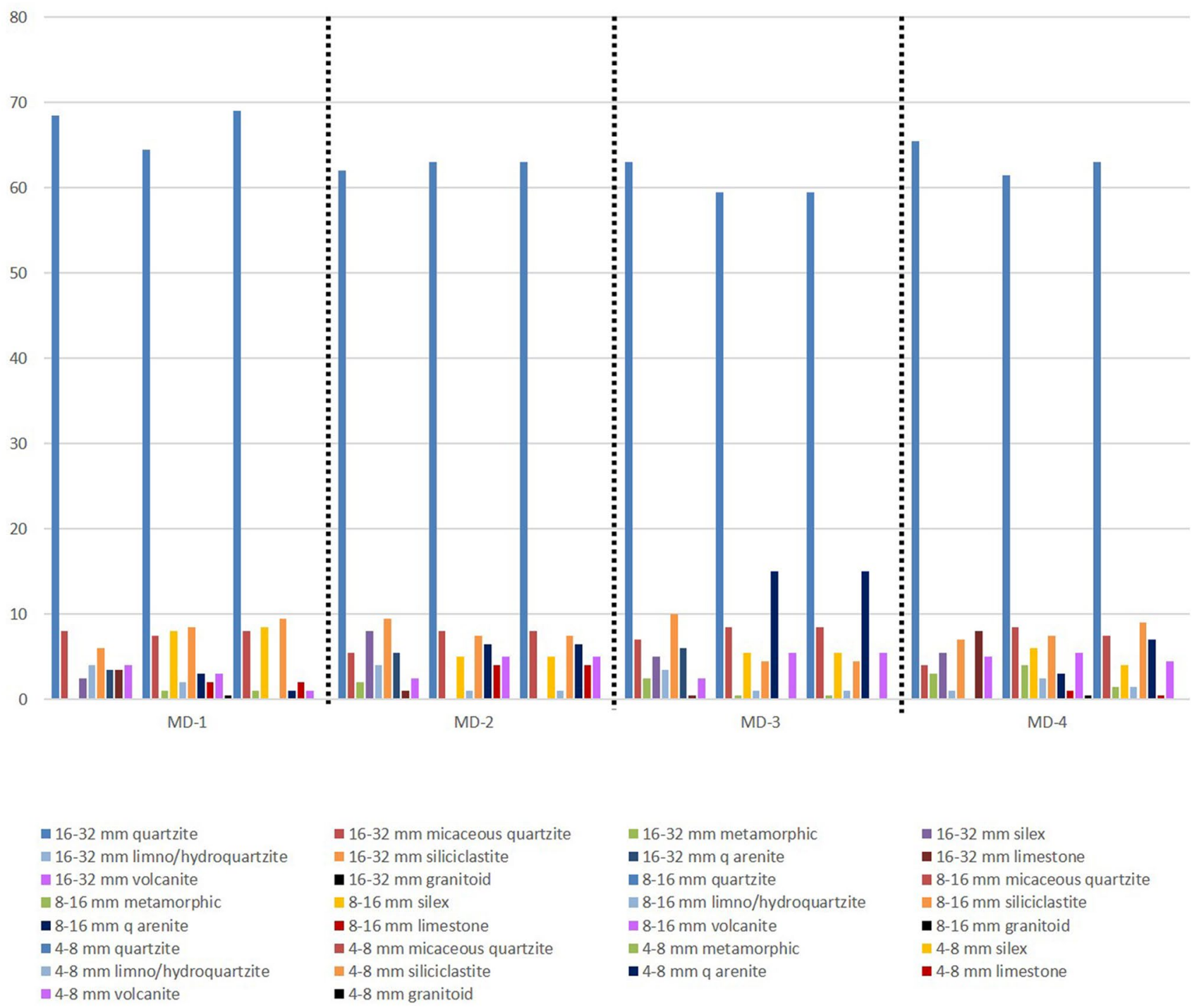

Fig. 4 Modal composition of 16-32-mm, 8-16-mm and 4-8-mm pebble fractions of the Mid-Danubian quarries (based on macroscopic petrographic examination)

\section{FPE of the 2-4-mm fraction}

The modal compositions of the studied 2-4 mm sediment fractions are presented in Figs. 6 and 7. A difference in the mineralogical maturity of sediments from the two regions is best indicated by the $<50 \%$ quartz-quartzite at Mid-Danubian sites (polymictic composition), while it is almost $60 \%$ at the NW Hungarian sites (oligomictic composition).

The four raw materials of the Mid-Danubian region have common features that can characterize the territory and the section of the fluvial depositional area (Fig. 6). These features are the predominance of quartzite (mono- and polycrystalline quartz lithoclasts) over other metamorphic rock types (e.g. micaceous quartzite, mica schist-gneissmetagranitoid rock fragments; 16-24\%), igneous rocks (volcanics and granitoids; 16-19\%) and sedimentary rocks (siliciclastites, limestone, silex; 3-10\%). The abundance of igneous and especially volcanic rocks (andesite) is significant. The quartzites often have sutured grain boundaries (with schistose oriented texture), but close-to-equilibrium (bulky non-oriented) texture is also present. The intra-grain crystal sizes are varied $\left(50-1500^{\circ} \mu \mathrm{m}\right)$. Monocrystalline quartz grains are very subordinated. Micaceous quartzite with oriented muscovite flakes is common. Subordinate phyllitic to gneissose rock fragments are also present. Plutonic rock fragments with microcline or plagioclase and 


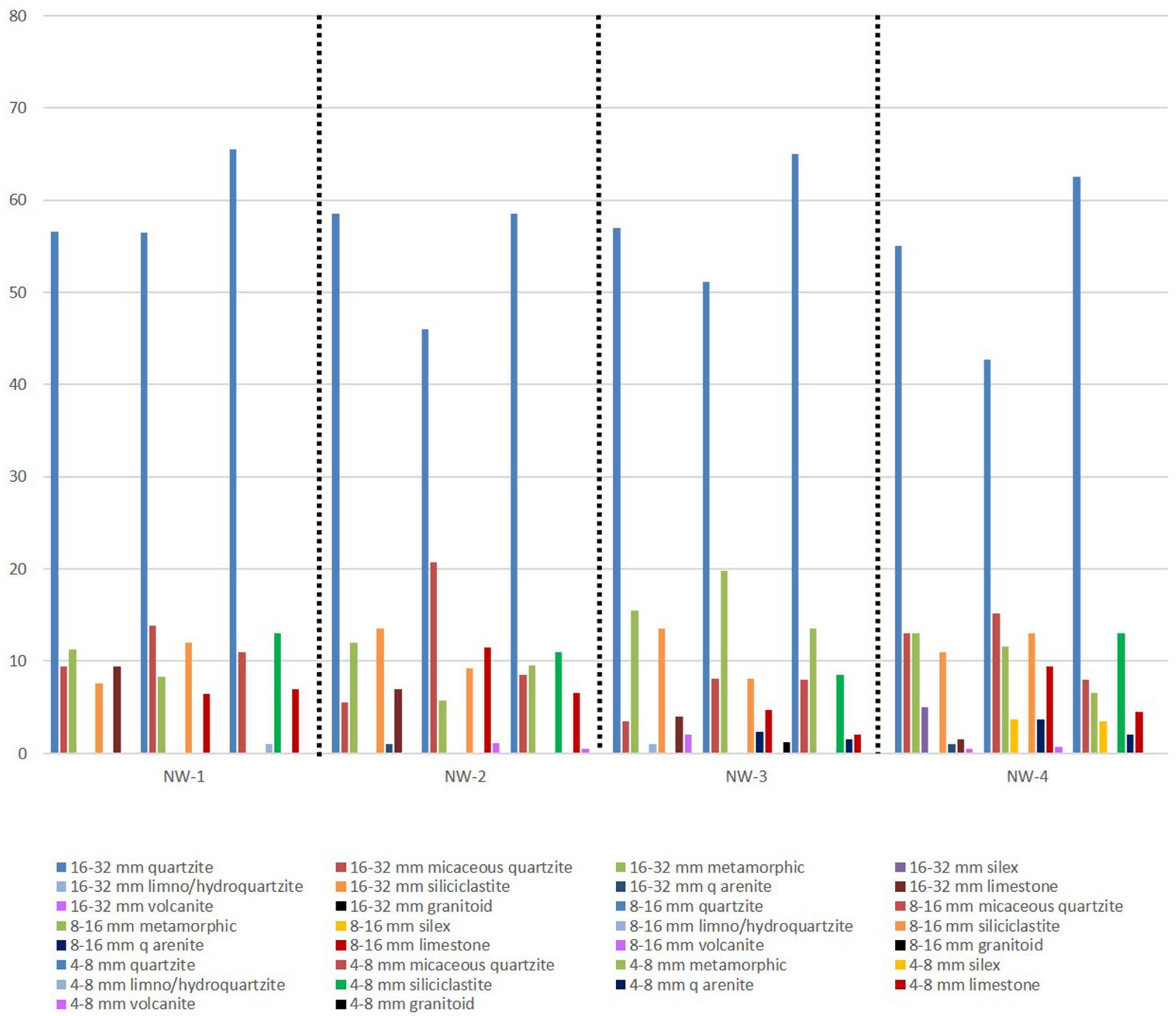

Fig. 5 Modal composition of 16-32-mm, 8-16-mm and 4-8-mm pebble fractions of the NW Hungarian quarries (based on macroscopic petrographic examination)

mafic minerals (e.g. green amphibole) can be observed. Monomineralic K-feldspar (sericitizated) or plagioclase clasts are granitoid originated fragments. Volcanics are predominantly andesites with plagioclase and mafic (biotite or amphibole) phenocrysts and glassy to plagioclase laths containing ground mass. Microcrystalline quartz (homogeneous or with veins) and radiolarite (both can be carbonated) are characteristic components. Micritic to sparry limestone, loess clasts and silt-sandstones (dominantly quartz-muscovite composition, but sometimes with calcareous cement or calcite grains) are also typical grain types.

The four raw materials of the NW Hungarian region have common features that can characterize the territory and the section of the fluvial depositional area (Fig. 7). The predominance of quartzite over other metamorphic rock types (9-16\%), igneous rocks $(3-11 \%)$ and sedimentary rocks (1-9\%) is more expressed and typical for these sediments than in the Mid-Danubian region. The compositions of the major rock groups are a bit different from the Mid-Danubian sediments: the igneous rocks are rather represented by feldspar mineral clasts than granitoid fragments (or volcanics); the sedimentary rock types are more varied and characteristic (fossiliferous limestone, carbonatizated radiolarite). In these sediments, the quartzites have sutured grain boundaries and variable intra-grain crystal sizes $\left(50-1000^{\circ} \mu \mathrm{m}\right)$. Monocrystalline quartz grains are more subordinate than in the Mid-Danubian samples. Quartzites that contain oriented muscovite flakes or rare feldspars are common. Subordinate 


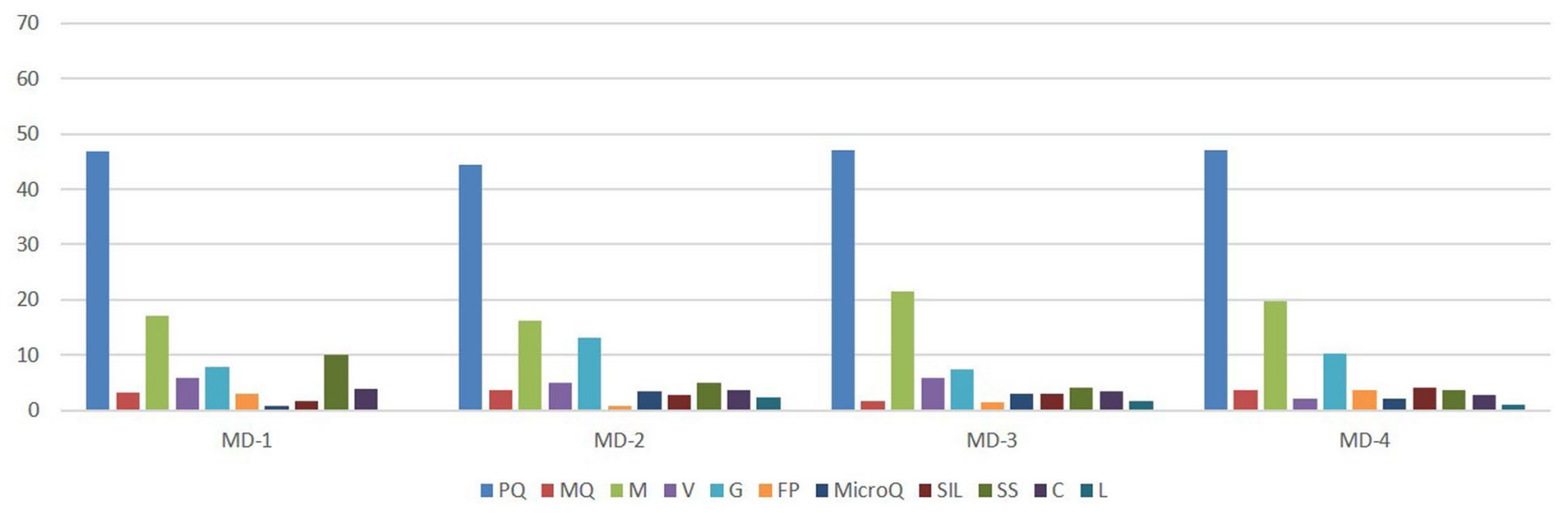

Fig. 6 Modal composition of 2-4-mm fine pebble fractions of the Mid-Danubian quarries (based on microscopic petrographic examination). Abbreviations: $\mathrm{PQ}$, polycrystalline quartz; MQ, monocrystalline quartz; M, metamorphic rock; V, volcanic rock; G, granitoid

gneissose-metagranitoid rock fragments are also present. Rare granitoid rock fragments and more common monomineralic microcline, sericitizated K-felspar or plagioclase clasts can be observed. Commonly carbonatizated microcrystalline quartz (homogeneous or with veins) and radiolarite are abundant and characteristic components. Micritic fossiliferous limestone and claystone-siltstone-sandstone-metasandstone (dominantly quartz-muscovite, sometimes calcareous or glauconitic composition) are also typical grain types.

Macro- and micro-scale pebble petrographies of the samples showed diagnostic differences among the two regions. All sampled sediments are dominated by metamorphic (and especially quartzite) rock originated clasts. Low-quartz-content metamorphics, igneous and siliciclastic sedimentary rock fragments are subordinate to quartzite content. Furthermore, pebbles of the Mid-Hungarian region contain a higher ratio of volcanic rocks, while gravels of the NW Hungarian region represent more mature sediments with a higher proportion of limestone. rock; FP, feldspar; MicroQ, microcrystalline quartz; SIL, siliciclastite and radiolarite; SS, claystone-siltstone-sandstone; $\mathrm{C}$, carbonatic rock; L, loess

The assessment of the potential ASR-sensitivity of aggregates was based on the quantification of micro-cryptocrystalline quartz $(<100 \mu \mathrm{m})$ and on the measurement of the undulatory extinction angle of 20 quartz crystals per sample after DeHills and Corvalán (1964) and the classification applied by Ramos et al. (2016) (after the Portuguese specification LNEC E 415 1993). According to the RILEM AAR-1.1 (2016) specifications, all the samples, due to their microcrystalline quartz content exceeding $2 \mathrm{w} \%$, have to be treated as class II (see Table 1). The significant amounts of potentially ASR reactive forms of silica in metamorphic rock fragments (Fig. 8) are micro-cryptocrystalline quartz, strained (deformed, stretched) quartz crystals with strain lamellae, subgraining and/or sutured/interlobate boundaries indicating bulging recrystallization (BLG), subgrain rotation recrystallization (SGR) or grain boundary migration (GBM) (Stipp et al. 2002; Krutilová and Přikryl 2017). According to Passchier and Trouw (2005), these microstructural characteristics indicate deformation and recrystallization under middle temperature regimes and

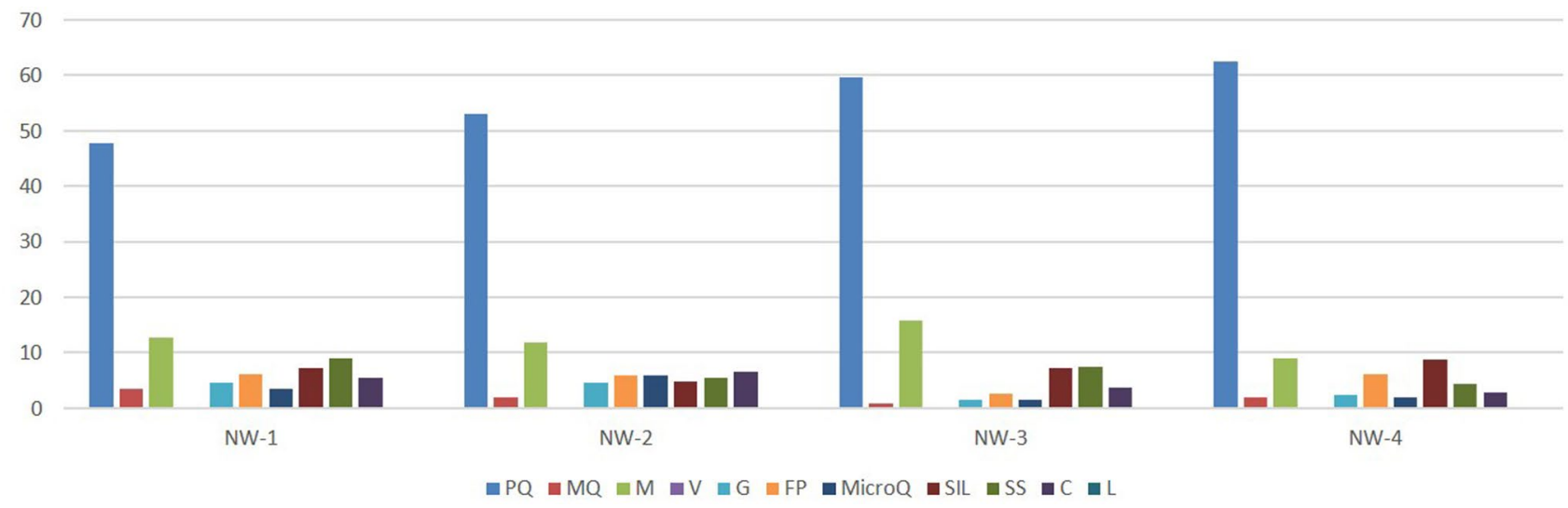

Fig. 7 Modal composition of 2-4-mm fine pebble fractions of the NW Hungarian quarries based on microscopic petrographic examination. Abbreviations: $\mathrm{PQ}$, polycrystalline quartz; $\mathrm{MQ}$, monocrystalline quartz; M, metamorphic rock; V, volcanic rock; G, granitoid rock; FP, feldspar; MicroQ, microcrystalline quartz; SIL, siliciclastite and radiolarite; SS, claystone-siltstone-sandstone; $\mathrm{C}$, carbonatic rock; L, loess 
Table 1 ASR-related

petrographic characterization of quartz in alluvial sandy gravel formations of Danube in Hungary (strain 1.: strain lamellae in quartz; ASR categories: class I: very unlikely to be alkali-reactive; class II: alkali-reactivity uncertain; class III: very likely to be alkali-reactive with aggregates containing opal or opaline silica)

\begin{tabular}{|c|c|c|c|c|c|}
\hline Aggregate & $\begin{array}{l}\text { Total quartz } \\
\text { content }(\%)\end{array}$ & $\begin{array}{l}\text { Potentially reactive } \\
\text { silica forms }(\%)\end{array}$ & $\begin{array}{l}\text { Reactivity class } \\
\text { (RILEM AAR-1.1) }\end{array}$ & $\begin{array}{l}\text { Undulatory } \\
\text { extinction angle }\end{array}$ & $\begin{array}{l}\text { Deformation } \\
\text { rate (LNEC } \\
\text { E415) }\end{array}$ \\
\hline MD-1 & 65.0 & $\begin{array}{l}<100 \mu \mathrm{m}: 25 \\
\text { Strain 1.: } 13 \\
\text { Sum: } 38\end{array}$ & Class II & $4-10^{\circ}$ & Weak \\
\hline MD-2 & 68.9 & $\begin{array}{l}<100 \mu \mathrm{m}: 28 \\
\text { Strain 1.: } 14 \\
\text { Sum: } 42\end{array}$ & Class II & $6-10^{\circ}$ & Weak \\
\hline MD-3 & 69.2 & $\begin{array}{l}<100 \mu \mathrm{m}: 24 \\
\text { Strain } 1 .: 2 \\
\text { Sum: } 26\end{array}$ & Class II & $7-12^{\circ}$ & Weak \\
\hline MD-4 & 71.7 & $\begin{array}{l}<100 \mu \mathrm{m}: 25 \\
\text { Strain 1.: } 6 \\
\text { Sum: } 31\end{array}$ & Class II & $9-12^{\circ}$ & Weak \\
\hline NW-1 & 70.7 & $\begin{array}{l}<100 \mu \mathrm{m}: 27 \\
\text { Strain 1.: } 3 \\
\text { Sum: } 30\end{array}$ & Class II & $5-7^{\circ}$ & Weak \\
\hline NW-2 & 73.9 & $\begin{array}{l}<100 \mu \mathrm{m}: 25 \\
\text { Strain 1.: } 2 \\
\text { Sum: } 27\end{array}$ & Class II & $5-8^{\circ}$ & Weak \\
\hline NW-3 & 77.7 & $\begin{array}{l}<100 \mu \mathrm{m}: 30 \\
\text { Strain 1.: } 5 \\
\text { Sum: } 35\end{array}$ & Class II & $4-7^{\circ}$ & Weak \\
\hline NW-4 & 80.9 & $\begin{array}{l}<100 \mu \mathrm{m}: 25 \\
\text { Strain } 1 .: 1 \\
\text { Sum: } 26\end{array}$ & Class II & $7-10^{\circ}$ & Weak \\
\hline
\end{tabular}

increasing dislocation density. It can be connected to relevant ASR potential (Wigum 1995; Wenk et al. 2008; Šachlová et al. 2017). In addition, micro-cryptocrystalline quartz or chalcedony/ moganite of siliceous limestone and radiolarite (Fig. 8) (similarly to cherts), and micro-cryptocrystalline matrix of fine-grained clastic sedimentary rock fragments (e.g. sandstone-siltstonegreywacke) also requires attention (e.g. Katayama 2004, 2010a; Marinoni et al. 2012; Šachlová et al. 2017). The potentially ASR

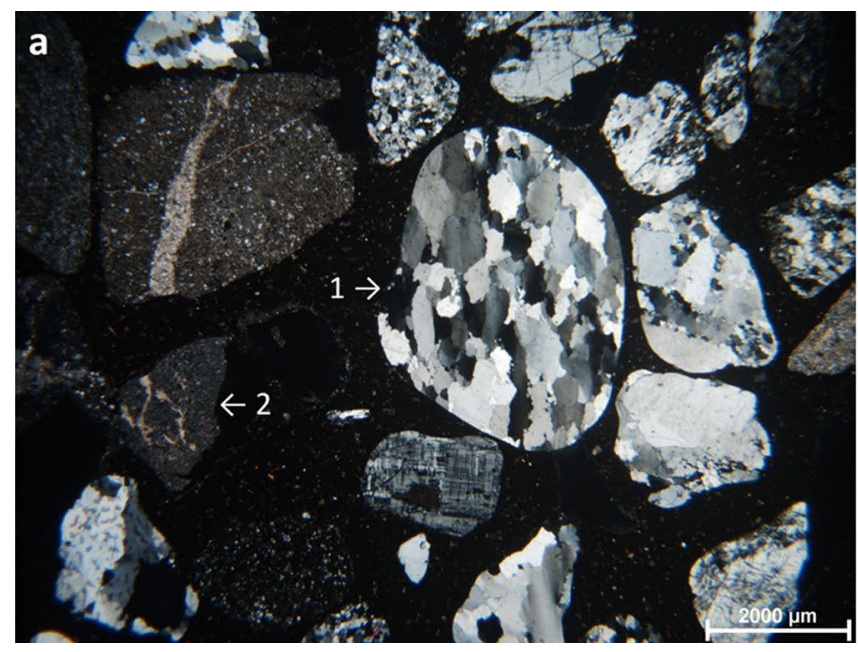

Fig. 8 Examples for ASR-reactive silica-rich grain types (1, crystalline quartzite; 2 , microcrystalline siliceous limestone and radiolarite) in the 2-4-mm fraction of aggregates exploited at a NW-2 and reactive forms of silica in subordinate amount $(>6 \%)$ of volcanic rock fragments are glassy or microcrystalline groundmass (Fig. 9). The neutral (silica) chemistry of andesitic rocks assumes an intermediate sensitivity to ASR (Katayama et al. 1989, Katayama 2010b; Medeiros et al. 2020). Due to their limited abundance in the grain mixture, siliceous limestone, radiolarite and volcanic lithofragments might act as detached (local) deterioration centers during ASR processes.

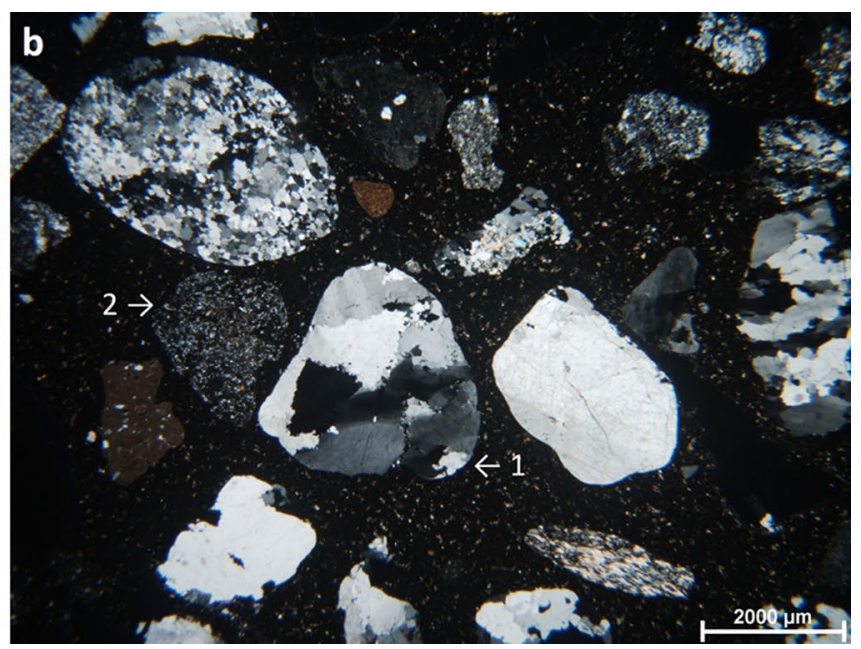

b MD-4. Note the quartzite grains with strained crystals of sutured boundaries and subgraining 

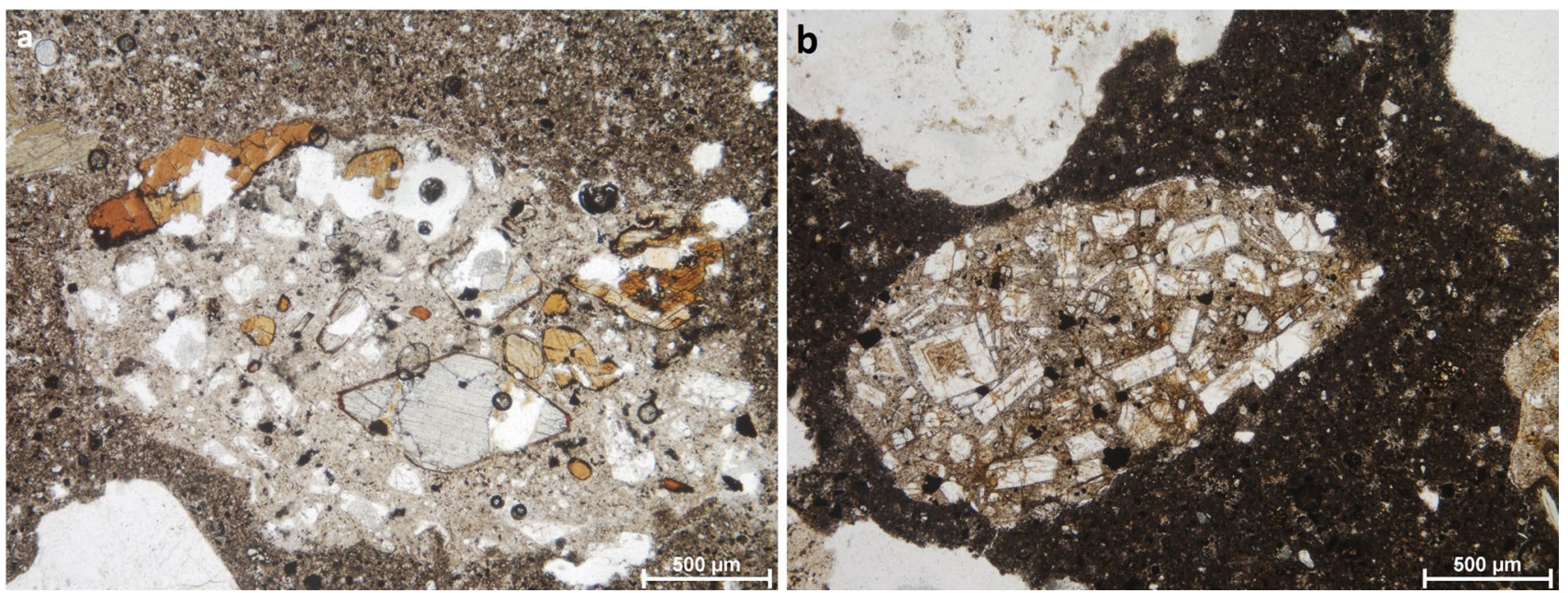

Fig. 9 Examples for ASR-reactive amorphous or microcrystalline groundmass in volcanic rock fragments in the 2-4-mm fraction of aggregates exploited at a MD-3 and b MD-4

Due to the variation of the characteristics of silica-rich aggregates inside a single quarry, the general specifications are conservative and require verification by expansion tests (e.g. accelerated mortar bar, concrete prism test). In addition, detailed SEM-PIA investigations (Šachlová et al. 2016, 2017) and CL microscopy (Krutilová and Přikryl 2017) would improve the knowledge on the ASR potential of each lithotype in the oligomictic natural mixtures.

\section{Heavy mineral analysis of the 63-125- and 125- 250- $\mu \mathrm{m}$ fractions}

The results of the heavy mineral investigations are illustrated in Fig. 10 and plotted in Fig. 11. The two size fractions consist of very similar mineral assemblage; thus, they are described together, but indicating their ratios within parentheses, first for fraction $125-250 \mu \mathrm{m}$ and then for fraction $63-125 \mu \mathrm{m}$.

Heavy mineral fractions of the Mid-Danubian region can be characterized by a variable mineral association containing rather simple monomineralic grains. The predominant garnet (23-55 and 27-33\%) is associated with abundant opaque minerals (10 and 17\%), green amphibole (8-13 and 16-18\%), epidote-zoisite (5-18 and 10-18\%), brown amphibole (2-12 and $8-13 \%$ ) and orthopyroxenes (6-12 and 4-12\%).

Oxiamphibole is a low quantity but characteristic phase (0-2\% and 1-10\%) (Fig. 11). The majority of the grains of these minerals are weakly rounded. The garnet is transparent and colorless (rarely rose). It is fragmented, xenomorphic/ anhedral, sometimes contains inclusions. Pyroxenes are fresh, hypidiomorphic/subhedral forms with characteristic serrated edges. Orthopyroxenes are olive green-brownish green pleochroic (with abundant opaque inclusions), while clinopyroxenes are almost colorless with weak pale red-pale green pleochroism. Opaque minerals are well-rounded, isometric grains. Hornblendes are dark green-bluish green-green-light green-yellow pleochroic, medium rounded, hypidiomorphic/ subhedral crysts. Zoisite-clinozoisite grains are colorless, medium rounded, porous structured and hypidiomorphic/subhedral. Additional (below 3\%) heavy mineral phases are siderite, chlorite, actinolite, limonite, tourmaline, staurolite, rutile, chloritoid, apatite, zircon, calcite, titanite, sillimanite, sericite, nontronite, tremolite, kyanite and muscovite. Complex lithic grains are low- to medium-grade metamorphic lithofragments (with zoisite, actinolite, green amphibole), micritic or sparry limestone.

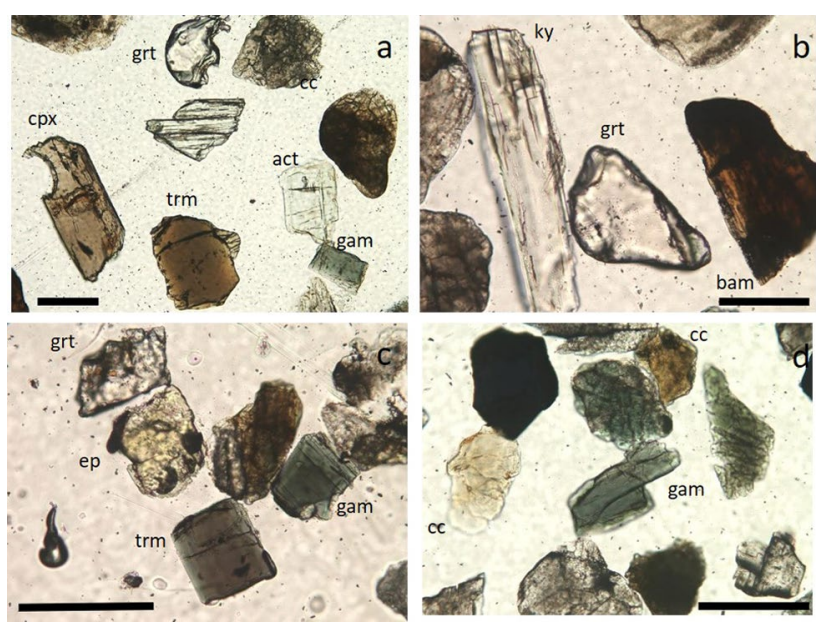

Fig. 10 Typical heavy mineral assemblages of sediments in the MidDanubian (a, b) and NW Hungarian (c, d) regions: a MD-2, 125-250 $\mu \mathrm{m}$ fraction; b MD-4, 125-250 $\mu \mathrm{m}$ fraction; c NW-4, 63-125 $\mu \mathrm{m}$ fraction; d NW-3, 63-125 $\mu \mathrm{m}$ fraction. The microscopic photographs were taken in plane polarized light, the scale is $100 \mu \mathrm{m}$. Abbreviations: grt, garnet; cpx, clinopyroxene; trm, tourmaline; act, actinolite; gam, green amphibole; ky, kyanite; ep, epidote; cc, calcareous lithofragment 

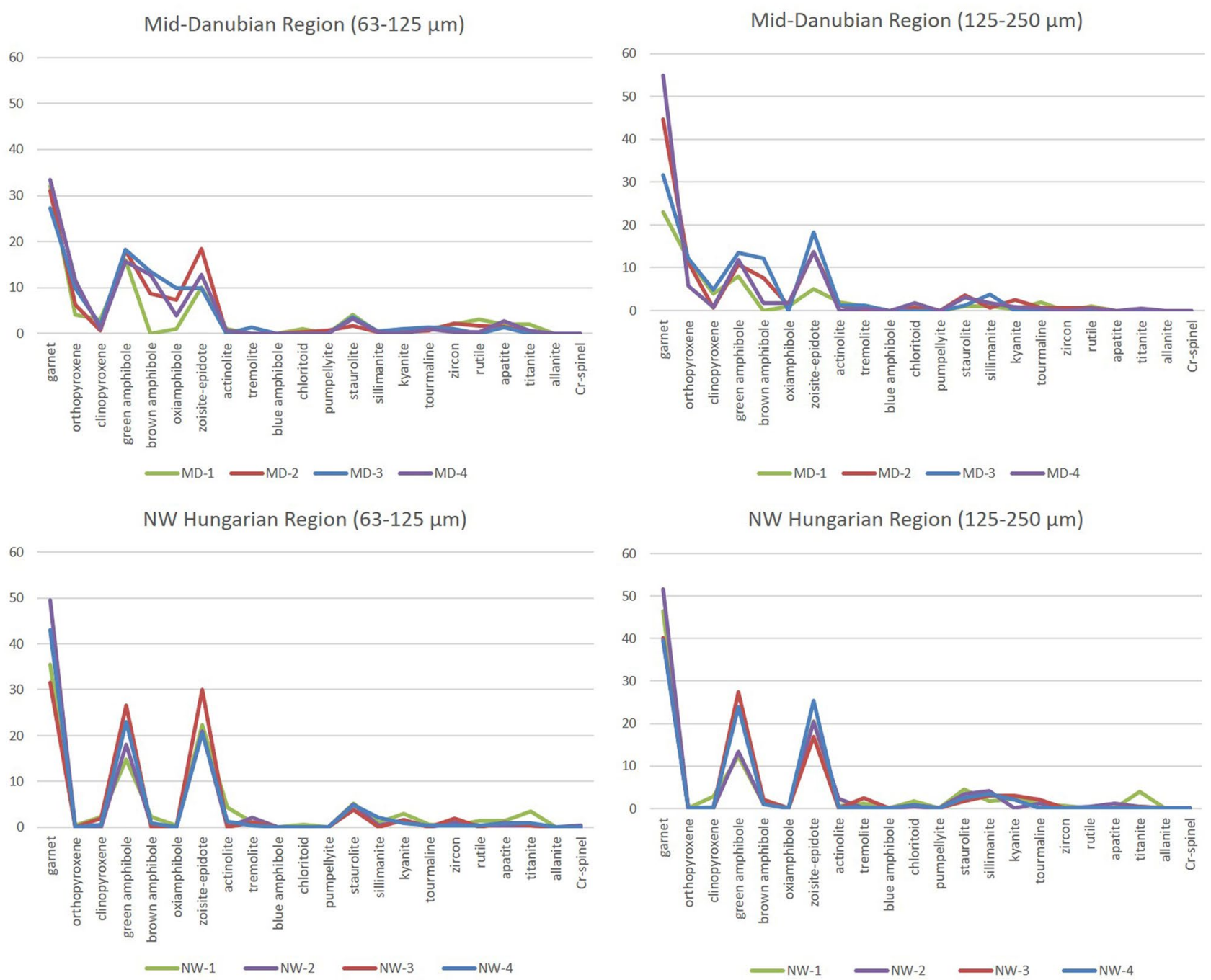

Fig. 11 Abundance (\%) of translucent heavy mineral species in the 63-125- and 125-250- $\mu \mathrm{m}$ fractions of sediments of the Mid-Danubian and NW Hungarian regions

The association of the NW Hungarian samples is also varied, containing dominantly monomineralic grains and subordinate amount (2-5\%) of metamorphic lithofragments (Fig. 11). The garnet is predominant (40-52\% and 32-50\%) together with the calcareous lithoclasts (both sparry and micritic, 18 and 33\%), and those are associated with abundant green amphibole (12-27\% and 15-27\%), zoisite-epidote (17-25\% and 21-30\%) and opaque minerals. Characteristic features are the low quantity of brown amphibole (1-2\% and 0-2\%) and the absence of orthopyroxene and oxiamphibole (Fig. 11). Majority of the grains of these minerals are weakly rounded, except for opaque minerals and micritic grains. The garnet is transparent and colorless (rarely rose) with fragmented, xenomorphic/anhedral shapes. Green amphiboles are clear, medium to dark green, pleochroic, hypidiomorphic/ subhedral, columnar forms with thin cleavage planes. Zoisiteclinozoisites are colorless, hypidiomorphic/subhedral, prismatic or isometric crystals. Epidotes are colorless-lemon yellow, pleochroic, hypidiomorphic/subhedral, prismatic or isometric crysts with dense fine-grained inclusions. Opaque minerals are rounded, isometric grains. Additional heavy mineral phases are chloritoid, staurolite, actinolite, kyanite, brown amphibole, clinopyroxene, rutile, apatite, sillimanite, tremolite, tourmaline and zircon. Complex lithic grains are metamorphic (greenschist, mica schist, graphitic-chloritic-sericitic phyllites, amphibolite) and calcareous lithofragments (sparry or micritic).

The heavy mineral assemblages of the two investigated regions show slight differences (Fig. 11). The main difference is the lithofragment content which is determined by the high limestone clast ratio at the NW Hungarian localities, while other (metamorphic) rock types are represented by similar abundances in the two regions.

The rich heavy mineral assemblage of the Mid-Danubian region has multi-source origin. They are partly derived from a metamorphic terrain (both the Bohemian Crystalline 
Massif and the Alps; Thamóné Bozsó 2002; Józsa et al. 2020; Arató et al. 2021): garnets with inclusions, green amphibole, brown amphibole, epidote-zoisite-clinozoisite, metamorphic lithofragments, chlorite, actinolite, tremolite, tourmaline, rutile, sillimanite, kyanite, staurolite and chloritoid. The other important part of the assemblage can be connected to younger volcanic sources (e.g. Miocene andesite-dacite of the Börzsöny-Visegrád Mts., Józsa et al. 2020): clear garnet, orthopyroxenes, opaque minerals, oxiamphibole and green hornblende. Siderite and limonite can have a local origin, as authigenic weathering products of the basal layers of the Pleistocene gravel formation. The limestone fragments and calcites can be connected to the Mesozoic or Miocene calcareous sedimentary formations of the surrounding mountains (Gerecse, Pilis, Buda Mts.; Thamóné Bozsó 2002).

The heavy mineral assemblage of the NW Hungarian region shows a narrower range with dominantly metamorphic originated garnet, green amphibole and epidote-zoisite-clinozoisite (tremolite, chlorite, actinolite, tourmaline, rutile, sillimanite, kyanite, staurolite, zircon) of the Bohemian Crystalline Massif,

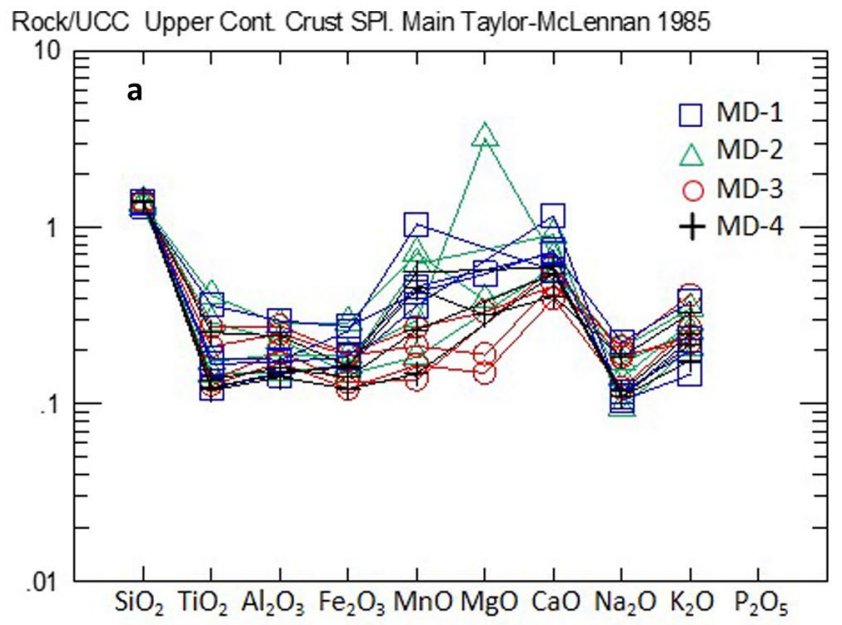

RockUCC2 Upper Cont. Crust SPI. B Taylor-McLennan 1985

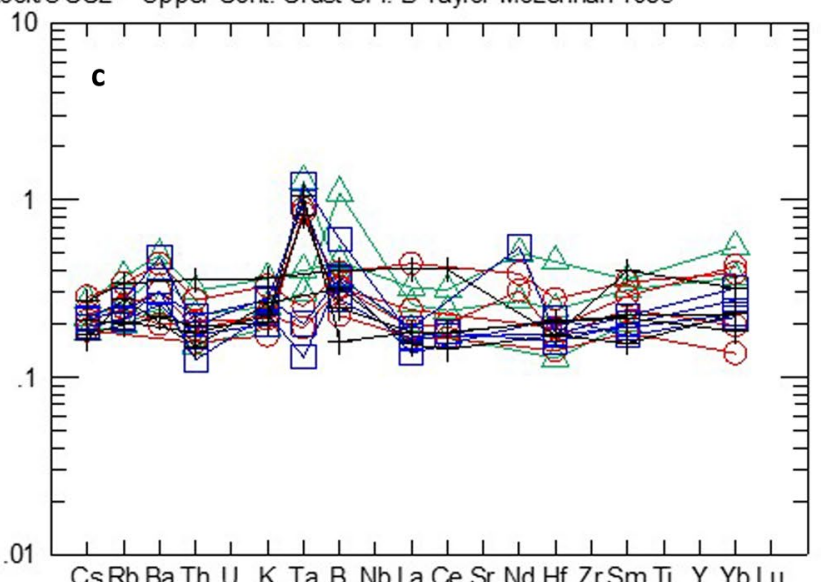

the Alps (Penninicum, Central Alps) and the NW Carpathians (Tatricum, Fatricum, Veporicum) (Thamóné Bozsó 2002; Józsa et al. 2020, Arató et al. 2021). Absence (e.g. orthopyroxene, oxiamphibole) or a very small amount (brown amphibole) of volcanic components indicates the upper course position of this region along the Danube flow without the contributions of the younger volcanic sources. Another feature is the significant amount of calcareous lithofragments (fine- to coarse-crystalline limestone) which can derive from the (Northern, Eastern or Central) Alps, the Leitha mountains or the NW Carpathians (Thamóné Bozsó 2002; Józsa et al. 2020, Arató et al. 2021).

\section{Chemical characterization of the 0-4-, 4-8-, 8-16- and 16-32-mm fractions}

Major, minor- and trace-element distributions of the Danube terrace sediments of the two studied sections are represented in Figs. 12 and 13. According to the conventions in geochemistry, the element distributions are normalized to geological reference materials to gain more comparable

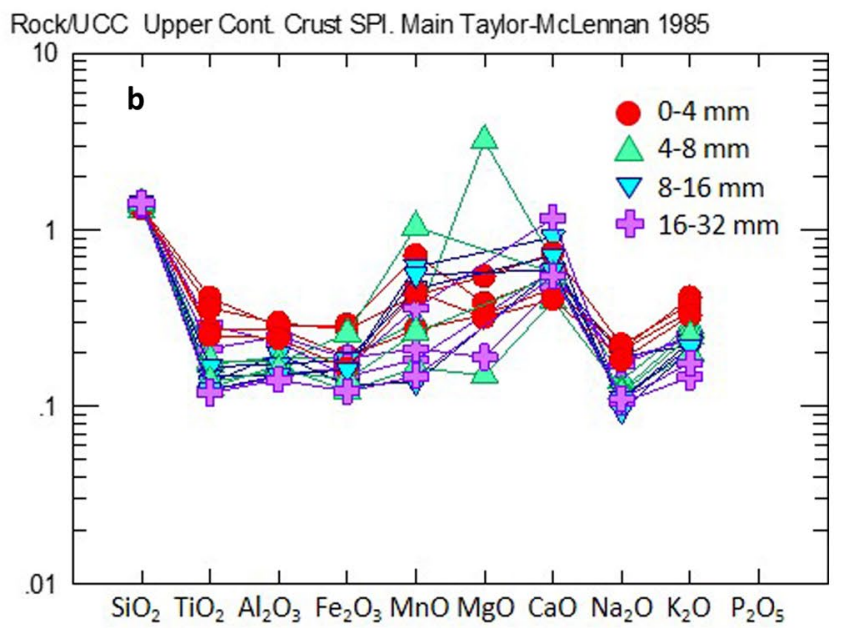

Rock/UCC2 Upper Cont. Crust SPI. B Taylor-McLennan 1985

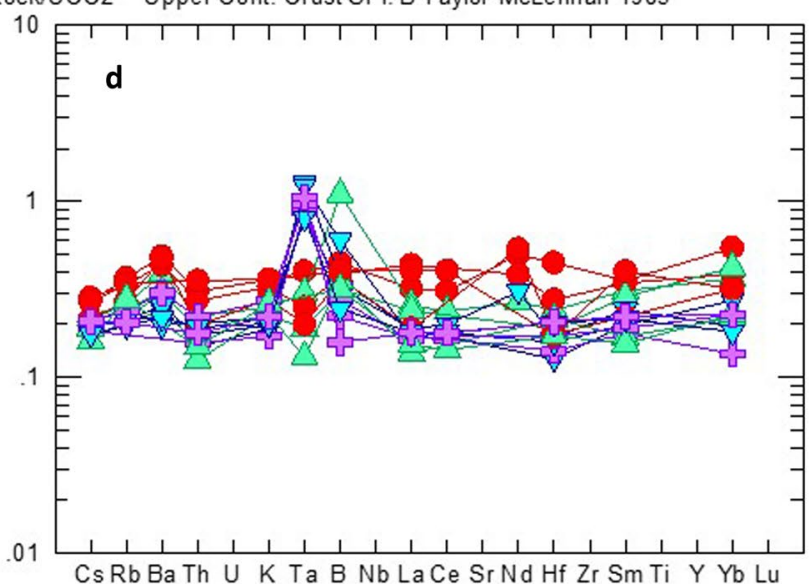

Fig. 12 Upper continental crust (UCC; Taylor and McLennan 1985) normalized major-minor and trace element distributions of 16-32-mm, 8-16-mm, 4-8-mm and 0-4-mm fractions of the Mid-Danubian sandy gravel quarries by localities and by grain sizes 

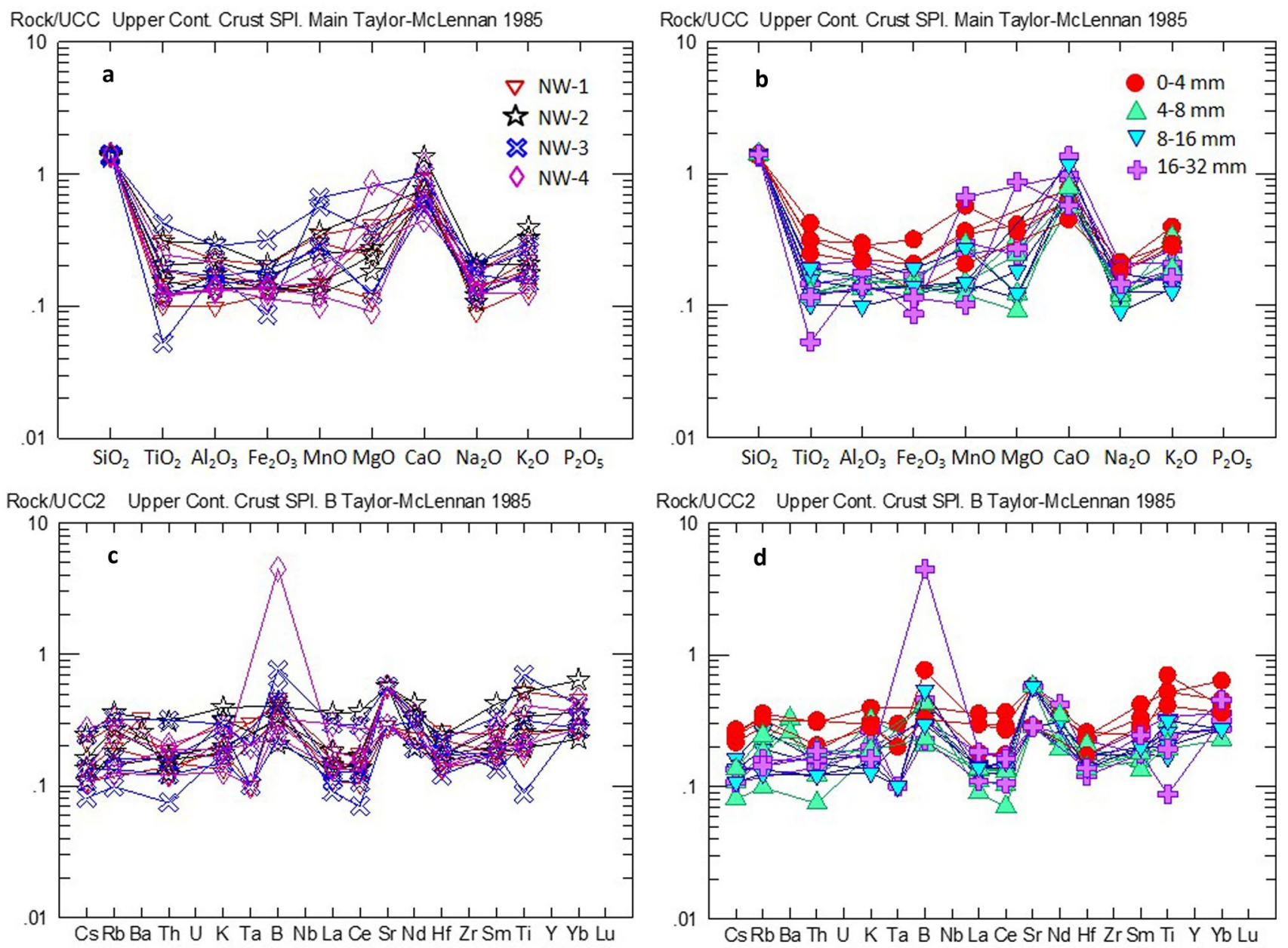

Fig. 13 Upper Continental Crust (UCC; Taylor and McLennan 1985) normalized major-minor and trace element distributions of 16-32-mm, $8-16-\mathrm{mm}, 4-8-\mathrm{mm}$ and $0-4-\mathrm{mm}$ fractions of the NW Hungarian sandy gravel quarries by localities and by grain sizes

data. In the case of clastic materials (sands, gravels), the upper continental crust (UCC) is an accepted reference average composition (Taylor and McLennan 1985; McLennan 2001). After normalizing our measured concentration data with this reference composition, difference from the unity expresses (negative) depletion or (positive) enrichment of certain elements compared to average clastic material composition. These normalized concentration profiles describe the geochemical behavior of the observed sediment. Major and minor elements (abundance in the Earth's crust is above $1 \mathrm{w} \%$ and $0.1 \mathrm{w} \%$, respectively) are presented in oxide form, while trace elements are in elemental form. The elements are sorted according to the geochemical conventions (considering the mobility and incompatibility of elements).

Quarried gravelly sediments of the Mid-Danubian region are characterized by $84-93 \mathrm{w} \% \mathrm{SiO}_{2}$; depletion in $\mathrm{Na}_{2} \mathrm{O}$ and $\mathrm{MgO}$ (the latter is often below the detection limit of the method); moderate depletion in $\mathrm{TiO}_{2}, \mathrm{Al}_{2} \mathrm{O}_{3}, \mathrm{Fe}_{2} \mathrm{O}_{3}$ and $\mathrm{K}_{2} \mathrm{O}$; and weak enrichment of $\mathrm{CaO}(1.6-4.9 \mathrm{w} \%)$, while by varied concentrations (with relatively high values) for $\mathrm{MnO}$ (Fig. 12). Sediments at MD-1 have small concentrations of $\mathrm{Fe}_{2} \mathrm{O}_{3}, \mathrm{MnO}$ and $\mathrm{CaO}$, while the gravels of MD-3 are the most enriched in these oxides. A common moderate depletion in all trace elements compared to the average reference composition can be observed with small discrepancies in boron and tantalum content (Fig. 12). The trace element contents are relatively consistent; there is no trend in the rare earth element (La-Lu) distribution. Based on the granulometry, a clear trend can be outlined: the finer the sediment the richer in minor and trace elements counter to $\mathrm{SiO}_{2}$ and $\mathrm{CaO}$. This enrichment is the most expressed for the $0-4-\mathrm{mm}$ fraction of the sediments, while it is less clear in the coarser fractions. Tantalum enrichment in the coarsest fractions can be detected.

Sediments of the NW Hungarian region have similar major element distribution to the Mid-Danubian region with 84-94 w\% $\mathrm{SiO}_{2}$ and depletion of elements except for $\mathrm{CaO}(1.8-4.9 \mathrm{w} \%)$. The only difference is the wider 
variation range of $\mathrm{TiO}_{2}, \mathrm{Fe}_{2} \mathrm{O}_{3}$ and $\mathrm{MnO}$ concentrations. The trace elements also show a comparable pattern to the other region but with more expressed depletion (Fig. 13).

The common geochemical feature of the two regions is the $\mathrm{CaO}$-enrichment and depletion in $\mathrm{MgO}$, while a very even, moderately depleted pattern was found for all trace elements. These are characteristic geochemical 'fingerprints' of the Danube sediments (comparing to clastic sediments of other gravel quarries in Hungary based on our own investigations). Based on these element profiles, the claimed origin of an industrial raw material can be validated on a regional scale.

\section{Discussion}

The comprehensive petrographic and geochemical investigation of alluvial sandy gravel formations of the middle course of the Danube shows that the main river of the Carpathian Basin has its peculiar petro-geochemical characteristics, distinguishable from other Hungarian gravel sources, and this determines its applicability to specific construction purposes.

It is common knowledge in concrete industry that the shape and texture of sand/gravel clasts influence the mechanical and fracture properties of concrete (e.g. Belhadj et al. 2014; Aïssoun et al. 2015) and on the transport properties which can positively influence durability potentialities of the composite (Hu and Stroeven 2006). Particle geometry influences abrasivity in petrographically homogeneous rock types (Hofer et al. 2013). The form of coarse aggregate (angularity is preferred) has a significant effect on the stability, rheology and compressive strength of concrete. Angular forms and spheric shapes improve the resistance of the concrete to crack propagation. On the contrary, there is a different requirement of the aggregate shapes in the asphalt industry. The morphological characteristics of fine aggregates can be correlated with the high-temperature viscoelastic properties of asphalt mixes (Wang et al. 2018), while it is less expressed for coarse aggregates. Crushed materials and manufactured gravels (with low roundness values) have more complex morphological characteristics, and those can effectively improve the deformation recovery, reduce the deformation of asphalt mixes, provide larger failure stress but lower failure strain. Another geotechnical parameter is granulometry which determines the fineness index.

Rock fabric characteristics (especially size descriptors) have significant influence on the engineering properties in general. In the case of oligomictic sandy gravels, the overall morphology of clasts is determined by the lithotypes. Although, grain-shape analysis of the Hungarian clastic sediments was not done, based on the macroscopic observations those have relatively homogeneous, well rounded and medium spheric character (see also Pécsiné Donát 1958). The grain populations are characterized by the balanced distribution of quartz-rich lithofragments to the metamorphic rock fragments with foliated texture and siliciclastic sedimentary rocks with a layered texture. The quartzose clasts have more isometric shapes while the foliated-layered rocks show more elongated forms. In addition, crushing the rock fragments with mica containing planes results in flaky shapes. The subordinate volcanic materials (in Mid-Danubian sediments) have well rounded and isometric shapes. The morphology of the pebble populations provides wide applicability of the sandy gravel raw materials. Tiny differences in the ratio of elongated clasts in the assemblages can impose some limitations to certain forms of use. The more elongated shapes obtained from crushing (due to their smaller mechanical resistance) imply that the crushed aggregates are less appropriate for use in road materials, coarse concrete aggregate and ballast for railways (Wenk et al. 2013). In addition, the observed Hungarian river-derived clastic raw materials are less appropriate for asphalt manufacturing due to their better roundness. For such purposes, the crushing of sandy gravel assemblages would be beneficial. The granulometry of the Hungarian clastic sediments was not observed in this study, but previous researches provided data. Burján (2002) evidenced that the sandy gravel sediments of the 1 st and 2 nd terraces in the Mid-Danubian region have similar granulometry (well sorted sediments with two-maxima distribution curves).

Mechanical adhesion between the aggregate and the cement paste is influenced by (1) the morphology of the aggregates, (2) chemical bonding and (3) chemistry of the cement. Both the (1) and (2) are affected by the composition of the aggregate. Silica-rich aggregates usually provide low adhesion to the binder in asphalt mixtures which results in weaker durability of the pavement surface (Anastasio 2015). Metamorphic rock aggregates (due to their weathering) can have weaker mechanical properties but better surface properties when used as concrete aggregate (Danielsen and Rueslltten 1984). The nature of chemical bonding can be characterized on different scales (Miller et al. 2011; Miller 2010; Lyne et al. 2013; Jones 1993). Micritic and dolomitic limestone, siliceous gravel and marble show significantly weaker chemical bonding (lower affinity to bond) with asphalt paste than other aggregates. Most other aggregates (metabasalt, quartzite and sandstone) exhibit stronger bonding affinity during asphalt- and asphaltic-concrete production (Miller et al. 2011; Hefer and Little 2005; Brand and Roesler 2017a, b). On the contrary, the chemical bonding functions in concrete mixtures in a more complex way (more reactive binder than asphalt) (Bentz et al. 2017). In concrete production, high-absorption limestones and marble performed very well (Shannon et al. 2015, 2017) and 
outperformed other aggregate types (e.g. metabasalt) in most cases, while siliceous gravel and granitic gneiss mixtures proved to be the weakest material (compressive, splitting and flexural strength). Matching the mechanical properties of the aggregate-paste couple can further improve the mechanical performance of concrete (Beushausen et al. 2015; Bremner et al. 1986; Aïtcin et al. 1990; Neville 1997; Sengul et al. 2002). Constituents with similar elastic modulus or coefficient of thermal expansion (volumetric changes during hydration) can result in lower-stress concentration (i.e. microcrack generation) at the interface of the two phases during loading. The incompatibility of properties of the aggregate-paste couple likely promotes the development of interfacial stresses, weakening the bond between the two phases and lowering the measured concrete strength.

The geotechnical properties of aggregates are determined by their petrographic-mineralogical composition. Textural features, grain size and grain boundary characteristics influence the uniaxial compressive, point load and tensile strengths, porosity, water absorption, specific gravity, the abrasivity, aggregate crushing and impact value and dynamic (P-wave velocity) characteristics (e.g. Pang et al. 2010; Rigopoulous et al. 2013; Sajid and Arif 2015; Er and Tuğrul 2016; Aligholi et al. 2019). In igneous rock system, fine-grained rocks with basic chemistry have higher engineering quality and lower abrasiveness potential than acidic and coarse-grained ones (Aligholi et al. 2019). However, contrary results were also published (Sajid and Arif 2015) where average coarse-grained texture with multi-modal distribution resulted in stronger matrix with lower porosity and water absorption values. Abrasivity is proved to correlate with quartz content and size rather than the grain shape or the chemical composition (Erichsen et al. 2011; Hofer et al. 2013; Er and Tuğrul 2016; Krutilová and Přikryl 2017). In long-term performance, resistivity to wear is also dependent on the petro-mineralogical composition and grain size (Gökalp et al. 2016)

Considering the above summarized observations on monomictic aggregates, some statements about multi-source aggregates and about the Hungarian alluvial sediments can be made. In the case of natural oligo-polymictic sandy gravel mixtures, the contrasting hardness of rock-forming minerals (i.e. the average mineralogical composition of the lithotypes) is determinative (Krutilová and Prrikryl 2017). It means that the predominance of the quartz-rich lithotypes (approx. $60-70 \%$ in MD and 40-60\% in NW samples) improves the resistivity to physical effect (abrasion, fragmentation). However, subordinate lithotypes (volcanites, sedimentary and low-quartz metamorphic rocks) will partly modify these values due to their heterogeneous texture (e.g. phenocryst content in volcanites; Krutilová and Přikryl 2017). Textural features (evolved interlocking of grain boundaries, recrystallized grain assemblages) of predominant quartzitic rock types in the Hungarian sandy gravels positively influence mechanical properties (e.g. compressive strength). The additional, non-quartzitic rock fragments can positively affect this when considering recrystallized textured volcanic (Török and Czinder 2017; Czinder and Török 2019, 2020) or fine-grained sedimentary lithotypes. The above-detailed studies demonstrate that the selection of an optimum aggregate for a specific concrete application is essential. In the case of the Hungarian alluvial clastic sediments, it is not possible to characterize the assemblages with a common material property since these have oligo- or polymictic composition with different rock types. Although the quartzite and quartz-rich lithotypes are predominant, at least $20 \%$ of the grain populations have different lithology which modifies the physical properties. Based on these preliminary observations, a detailed laboratory testing (e.g. micro-Deval, UCS, PSV tests) is planned to provide quantitative data for asphalt fillers or road surfacing concrete applications.

Based on the analytical and petrological results, all sand and gravel samples have $\mathrm{SiO}_{2}$ content over $80 \mathrm{w} \%$. It is present in different silica forms, i.e. macro-microcrystalline quartzite, cryptocrystalline radiolarite and macrocrystalline quartz content of granitoid rocks, volcanites or sandstones. In addition, $\mathrm{SiO}_{2}$ is also a major component of the silicate minerals (feldspar, amphibole, mica, clay minerals) of metamorphic and igneous rocks. The major constituents besides $\mathrm{SiO}_{2}$, are $\mathrm{Al}_{2} \mathrm{O}_{3}, \mathrm{Fe}_{2} \mathrm{O}_{3}, \mathrm{~K}_{2} \mathrm{O}$ and $\mathrm{Na}_{2} \mathrm{O}$. Aluminium is mainly related to the alumo-silicates, especially clay minerals. The alkalies and the iron are also major components of the silicate minerals. The $\mathrm{CaO}$ content is relatively high in both regions (1.6-4.9 w\%) which is almost entirely derived from the calcareous (mainly limestone) lithofragments. Chemical composition analyses of the samples rated as a function of particle size revealed that elemental variability increases with decreasing grain size, i.e. the coarser pebble fractions contain more quartz-quartzite. Trace element distribution of sand and gravel samples show moderate depletion relative to UCC which indicates the relatively mature character of these sediments. All the trace element concentrations decrease with increasing particle size, except for $\mathrm{Cr}$, which has a larger concentration in gravels than in sands. Gravels of the Mid-Hungarian MD-1 and 2 quarries have the lowest trace element contents.

The pebble petrography indicates relatively high maturity with quartz-dominated metamorphic-metagranitoid rock fragments, as a weathering product of crystalline rocks. The subordinate role of sedimentary and volcanic rocks is related to local sources (input from tributaries). Fine pebble petrography showed similar compositions to the macro-scale data but with diagnostic differences between the two regions. All the sampled sediments are dominated by metamorphic quartzite clasts, while low-quartz-content metamorphics, igneous and siliciclastic sedimentary rock fragments are 
subordinate. In the Mid-Hungarian region, volcanic rocks are more significant; on the contrary, in the NW Hungarian region, limestone is characteristic. The heavy mineral analysis also confirms this observation. In addition, the MidDanubian region has alluvial sediments with a multi-source origin (metamorphics of both the Bohemian Massif and the Alps; younger volcanites of Börzsöny-Visegrád Mts.; limestones of Gerecse/Pilis/Buda Mts.), while the NW Hungarian Danube sediments are less varied (metamorphics of both the Bohemian Massif, the Alps and the NW Carpathians; limestones of Alps/Leitha Mts./NW Carpathians) (Thamóné Bozsó 2002; Bradák et al. 2014; Szeberényi et al. 2014; Józsa et al. 2020; Arató et al. 2021). Due to the high silicate content (i.e. a high water-affinity), the observed alluvial sediments are relatively susceptible to stripping (incompatible to asphalt), so their use as raw materials in asphalt industry is less favorable.

Bulk chemical composition of monomictic aggregates usually is considered during prediction of ASR potential (e.g. volcanites, Medeiros et al. 2020; Krutilová and Přikryl 2017), especially when the petrographic modal analysis is impossible due to the very fine-grained nature of the studied rocks. Another application of major element composition is for evaluation of abrasion resistivity (Er and Tuğrul 2016). In our research, we aim to apply the minor and trace element compositions to predict the activation risk of aggregates in a radiation environment, e.g. in the shielding concrete of nuclear facilities (power plants, research infrastructures). Concrete structures in such facilities are exposed to high doses of ionizing radiation and therefore can suffer mechanical degradation, and radioactivity might be induced during their service period, depending on their isotope composition (Ichikawa and Koizumi 2002; Denisov et al. 2012; Saouma and Hariri-Ardebili 2014; Pignatelli et al. 2016; Rosseel et al. 2016). Long-lived radioisotopes remain radioactive long after the shutdown of the facility (Islam et al. 2016) which requires special attention during the decommissioning. To produce radiation-resistant concretes with low activation susceptibility it is essential to select the proper ingredients, e.g. aggregates that contain the isotopes forming later the long-lived radionuclides only in low quantities. Heavy mineral studies have been done to complement and support the results of elemental analysis. It is known from the literature that the trace elements responsible for the long-lived radioactivity are enriched in heavy minerals of the sand and gravel (Islam et al. 2016). The chemical compositional study revealed significant differences among trace element abundances of sandy gravels from the NW Hungarian and the MidDanubian regions. In the case of Hungarian clastic sedimentary formations, the problematic isotopes are found to be accumulated in mineral species like garnet (Shimizu 1975; Smith et al. 2004; Ranjbar et al. 2016; Warren et al. 2018), amphibole (Parker and Fleischer 1968; Li et al. 2017), pyroxene (Shimizu 1975; Smith et al. 2004), rutile (Meyer et al. 2011) or zircon (Belousova et al. 2002; Claiborne et al. 2010).
It can be highlighted that there are some aggregates with a remarkably lower or higher 'impurity profile', originating from different mines within the Hungarian alluvial sediments. Impurity has a different context when concretes of open-air supporting or inside structures subjected to heat or other intensive radiation are considered. For outdoor concrete walls or blocks, the harmful constituents that are sensitive to chemical attack (e.g. sulphate or ASR) are the micro-cryptocrystalline $\mathrm{SiO}_{2}$ varieties, iron sulfides, ferric and ferrous oxides, free lime and free magnesia (with alkali-, oxidation-, hydration- or carbonatization-reactive chemical properties). For indoor concretes suffering continuous thermal, electromagnetic or particle radiation, the activation potential of the constituents is an additional fundamental parameter; this is determined by the chemical isotope contents carried in by the mineral phases. In the observed samples the sole harmful component is the high silica content in varied forms. However, its high concentration anticipates the possibility of the pessimum behavior (Stanton 1940; Hobbs 1988) without the danger of ASR processes. In addition, ASR assessment needs to consider the cumulative amount of coarse and fine aggregates, in order to evaluate the behavior of the material. During the investigation of British river, glacial, beach and marine gravel deposits of aggregates, Rayment et al. (1990) found that the most ASR-reactive constituents are the cherts (due to microchalcedony content), siliceous mudstone-limestone (due to crypto-microcrystalline silica and chalcedony), metaquartzite and slightly metamorphozed sandstone (due to strained quartz). For Scottish sand and gravel deposits, any harmful constituents owned only a small proportion due to the very varied polymictic composition. These results indicate that the multi-source composition of alluvial to marine deposits can significantly affect the behavior of the aggregate. Well-known reactive minerals are reactive silica (micro- or cryptocrystalline quartz, submicroscopic or disordered quartz, strained quartz, opal, calcedony, tridymite, cristobalite, devitrified glass) and fine-grained greywacke (e.g. French 1991; Beck et al. 2000; Danielsen and Nebdal Svendsen 1991, Anastasio et al. 2016) and may be present in aggregates in small amounts ( $2 \mathrm{w} \%$ opal, 20 w\% greywacke).

Alkali-reactivity of some rock types commercially used in Hungary was assessed (Fernandes et al. 2018). Felsic (sandstone, granite) and intermediate rocks (andesite) proved to have a higher potential to alkali-silica reactivity than basic rocks (diabase) due to their higher silica content. However, further studies, recommendations or guidelines are not provided on a domestic scale. A more detailed study on commercially used and available aggregate types was published and recommended by Fernandes et al. (2016). ASR sensitivity of granitic and quartzite rocks was also investigated (Kerrick and Hooton 1992; Monnin et al. 2006; Hagelia and Fernandes 2012; Ramos 
et al. 2011, 2016). Dolar-Mantuani (1983) and West (1991, 1994) pointed out the undulatory extinction angle as a possible indicator. According to Ramos et al. (2016), there is a positive but moderate - correlation between the amount of microcrystalline quartz, the undulatory extinction angle and the ASR potential (especially in the lower value region of the plot). However, other authors claimed that there is a direct correspondence between the undulatory extinction angle of quartz and ASR sensitivity (Andersen and Thaulow 1989; Ramachandran and Beaudoin 2000). They related the ASR potential of aggregates to their micro-cryptocrystalline silica content. According to the Concrete Society (1987), aggregates containing $>30 \%$ highly strained quartz (av. UEA $>25^{\circ}$ for min. 20 quartz crystals) are regarded as potentially alkali-silica reactive.

In the observed Hungarian alluvial sandy gravel formations, the predominant strained quartz component $(>60 \%)$ belongs to the weakly deformed type (UEA $\left.<14^{\circ}\right)$. However, about onethird of this silica (20-25\%) has an average grain size below $100 \mu \mathrm{m}$ which has to be considered as deleterious component (though only a subordinate part can be attributed to chalcedony). This amount determines the sediments to be potentially reactive (Class II) to ASR. In addition, the textural characteristics of the dominant quartzite lithotype implies that ASR microcracks might rather appear along aggregate grains, while intra-grain cracking would be rare (Šachlová et al. 2016, 2017).

Further lithotypes with potential ASR (schist-metagranitoid, granitoid, andesite, siliceous limestone, radiolarite) can show alkali content which proved to be an inert feature in the alkali access of ASR processes (Drolet et al. 2017). Studies on monomictic volcanic aggregates (e.g. basalts; Korkanç and Tuğrul 2005; Medeiros et al. 2020) indicated ASR-related microcracking along the aggregate grains; though, this phenomenon was affected by the glass content of volcanites. In case of the Hungarian oligomictic formations, neutral volcanites (mainly andesite) contain fresh or recrystallized matrix carrying the ASR sensitivity.

Alkali-silica reactivity is a deleterious process especially in open-air concrete structures (concrete roads, bridges) where those are directly exposed to humidity. It can also have potential in large and thick concrete structures (e.g. some meters thick constructions) where real dry state of the body can never be reached. Besides, high-temperature environment can also accelerate the initiation of ASR (e.g. heating systems, radiation-induced heating load). These application fields of concrete can be impacted by ASR damage if the investigated Hungarian aggregates are used.

\section{Conclusion}

This paper evaluates the applicability of Hungarian oligomictic alluvial gravel formations for concrete and asphalt manufacturing. These specific sediments of the Danube, one of the main rivers of Europe, bear the traces of a complex formation history with multiple sources. This makes these aggregate types less strictly classifiable than monomictic rock aggregates exploited in open-air pits. Multi-source clastic sediments cannot be determined by single values of physical properties but can behave more flexible and less predictable than monomictic aggregates. A detailed petrographic and textural characterization is even more important than for monomictic materials and can provide a suitable complement to reliably predict engineering properties of oligo-polymictic sedimentary rocks. Complementary chemical and heavy mineral investigations proved to be useful in evaluation of the activation potential of aggregates for application in radiation shielding concrete structures.

It was an aim to link the petrological characteristics of the gravel formations and their possible applications in the concrete and asphalt industry field. These so far missing or undervalued parameters are decisive for many civil engineering properties and can improve the dialogue between specialists and the producers. A future geotechnical assessment will be necessary to reveal aggregates that are satisfactory for use in specific construction fields.

The two regions on the middle course of the Danube Mid-Danubian and NW Hungarian regions - have similar sandy gravel formations on the bases of macro-microscopic petrographic, heavy mineral and geochemical investigations. However, moderate differences deriving from the distinct geological positions on the river section could be revealed. Due to their chemical and petrographic compositions, the investigated gravel formations from Hungary are appropriate aggregates for conventional applications of concrete (e.g. house walls, basements), while their application to openair constructions (e.g. bridges, concrete covering of roads) might be problematic due to their possible alkali-silica reactivity. For such purposes, crushed clastic materials of monomictic composition (mined rock types) are the better choice in case of low ASR properties. Another option is the use of supplementary cementitious materials or blended cements which can control ASR or limit the alkali content of the concrete. The direct application of these Hungarian alluvial gravel formations for road construction purposes is more appropriate than for asphalt manufacturing or railways ballast for which utilization crushed gravel would be beneficial.

Acknowledgements We would like to thank the owners and the staff $f$ the observed mines to make us possible the sampling on their properties. The authors are grateful to the anonymous reviewers of the manuscript.

Author contribution $\mathrm{SzV}$ completed the macro- and microscopic examinations, participated in the fieldwork, compiled, synthetized and interpreted the data and drafted the manuscript. GK led the fieldwork, measured and evaluated the NAA data, compiled and interpreted the geochemical data and revised the manuscript. JS prepared the samples for microscopic investigations, investigated the heavy mineral fractions, 
interpreted those data and revised the manuscript. HI participated in the fieldwork, measured and evaluated the PGAA data. SzL revised the manuscript and managed the related research grant.

Funding Open access funding provided by ELKH Wigner Research Centre for Physics. The fieldwork, the macro- and microscopic investigations and the analytical measurements were carried out in the framework of the project No. 127102 RADCON that has been implemented with the support provided from the National Research, Development and Innovation Fund of Hungary, financed under the NN_17 V4-Korea funding scheme.

\section{Declarations}

Conflict of interest The authors declare no competing interests.

Open Access This article is licensed under a Creative Commons Attribution 4.0 International License, which permits use, sharing, adaptation, distribution and reproduction in any medium or format, as long as you give appropriate credit to the original author(s) and the source, provide a link to the Creative Commons licence, and indicate if changes were made. The images or other third party material in this article are included in the article's Creative Commons licence, unless indicated otherwise in a credit line to the material. If material is not included in the article's Creative Commons licence and your intended use is not permitted by statutory regulation or exceeds the permitted use, you will need to obtain permission directly from the copyright holder. To view a copy of this licence, visit http://creativecommons.org/licenses/by/4.0/.

\section{References}

Ahmad M, Ansari MK, Rajesh Singh L, Sharma LK, Singh TN, Pires S (2018) Assessment of potential alkali aggregate reactivity for siliceous and carbonate aggregates: a case study. J Geol Soc India 91(4):467-474

Aïssoun B, Hwang SD, Khayat KH (2015) Influence of aggregate characteristics on workability of superworkable concrete. Mat Struc. https://doi.org/10.1617/s11527-015-0522-9

Aitcin PC, Mehta P (1990) Effect of coarse aggregate characteristics on mechanical properties of high-strength concrete. ACI Materials J 87(2): 103-107

Alexander M, Mindess S (2005) Aggregates in Concrete. CRC Press, London

Aligholi S, Lashkaripour GR, Ghafoori M (2019) Estimating engineering properties of igneous rocks using semi-automatic petrographic analysis. Bull Engin Geol Environ 78:2299-2314

Anastasio S (2015) Evaluation of the effect of aggregate mineralogy on the durability of asphalt pavements. Dissertation, Norwegian University of Science and Technology.

Anastasio A, Perez Fortes AP, Kuznetzova E, Danielsen SW (2016) Relevant petrological properties and their repercussions on the final use of aggregates. Energy Procedia 97:546-553

Andersen KT, Thaulow N (1989) The application of undulatory extinction angles (UEA) as an indicator of alkali-silica reactivity of concrete aggregates. In: Okada K, Nishibayashi S, Kawamura M (eds) $8^{\text {th }}$ International Conference on Alkali-Silica Reaction. CRC Press, Kyoto, pp 489-492

Arató R, Obbágy G, Dunkl I, Józsa S, Lünsdorf K, Szepesi J, Molnár K, Zs Benkó, von Eynatten H (2021) Multi-method comparison of modern river sediments in the Pannonian Basin System - A key step towards understanding the provenance of sedimentary basin-fill. Global and Planetary Change. https://doi.org/10.1016/j. gloplacha.2021.103446

ASTM C 295 (2019) Standard guide for petrographic examination of aggregates for concrete, ASTM International, West Conshohocken, PA.

ASTM C 1260 (2014) Standard test method for potential alkali reactivity of aggregates (Mortar-Bar method), ASTM International, West Conshohocken, PA.

ASTM D 3398 (2000) Standard test method for index of aggregate particle shape and texture, ASTM International, West Conshohocken, PA.

ASTM D 4791 (2019) Standard test method for flat particles, elongated particles, or flat and elongated particles in coarse aggregate, ASTM International, West Conshohocken, PA.

Beck JB, Burcharth H, Danielsen S, Helgason E, Frigaard P (2000) The use of gabbro rock armour in rubble mound structures. In: Losada IJ (ed) Coastal structures '99. CRC Press/Balkema Publishers, The Netherlands, pp 249-254

Belhadj B, Bederina M, Bangeuttache K, Queneudec M (2014) Effect of the type of sand on the fracture and mechanical properties of sand concrete. Adv in Conc Constr 2(1):13-27

Belousova E, Griffin W, O’Reilly SY, Fischer N (2002) Igneous zircon: trace element composition as an indicator of source rock type. Contrib Mineral Petrol 143:602-622

Bentz DP, Arnold J, Boisclair MJ, Jones SZ, Rothfeld P, Stutzman PE, Tanesi J, Beyene M, Kim H, Muñoz J, Ardani A (2017) Influence of aggregate characterization on concrete performance. NIST Technical Note 1963, NIST, US Dept. of Commerce.

Berubé MA (2001) The mineralogical and petrographic analysis of concrete aggregates. JOM 53:45-47

Beushausen H, Dittmer T (2015) The influence of aggregate type of the strength and elastic modulus of high strength concrete. Constr Build Mat 74:132-139

Bradák B, Kiss K, Barta G, Gy Varga, Szeberényi J, Józsa S, Novothny Á, Kovács J, Markó A, Mészáros E, Szalai Z (2014) Different paleoenvironments of Late Pleistocene age identified in Verőce outcrop, Hungary: Preliminary results. Quat Int 319:119-136

Brand AS, Roesler JR (2017) Bonding in cementitious materials with asphalt-coated particles: part $\mathrm{i}-$ the interfacial transition zone. Constr Build Mat 130:171-181

Brand AS, Roesler JR (2017) Bonding in cementitious materials with asphalt-coated particles: part ii - cement-asphalt chemical interactions. Constr Build Mat 130:182-182

Bremner T, Holm T (1986) Elastic compatibility and the behavior of concrete. ACI Materials J 83(2):244-250

Bulla B (1941) A Magyar medence pliocén és pleisztocén teraszai. Földrajzi Közlemények 69:199-230

Burján B (2002) A Pesti-síkság kavicsos üledékeinek szemcseeloszlás vizsgálata. Földtani Közlöny 132/spec:161-173.

Claiborne LL, Miller CF, Wooden JL (2010) Trace element composition of igneous zircon: a thermal and compositional record of the accumulation and evolution of a large silicic batholith, Spirit Mountain, Nevada. Contrib Mineral Petrol 160:511-531

Concrete Society (1987) Alkali-silica reaction: minimizing the risk of damage to concrete, guidance notes and model specification clauses. Concrete Society, Technical Report No.30., London, U.K.

CRD-C-120 (1994) Test method for flat and elongated particles in fine aggregate. U.S. Army COE Standards.

Czinder B, Török Á (2019) Effects of long-term magnesium sulfate crystallisation tests on abrasion and durability of andesite aggregates. Bull Eng Geol Environ. https://doi.org/10.1007/ s10064-019-01600-4

Czinder B, Török Á (2020) Strength and abrasive properties of andesite: relationships between strength parameters measured on cylindrical test specimens and micro-Deval values-a tool for durability 
assessment. Bull Eng Geol Environ. https://doi.org/10.1007/ s10064-020-01983-9

Danielsen SW, Rueslítten HG (1984) Feldspar and mica. Key minerals for fine aggregate quality. Bull Engin Geol Envir 30:215-219

Danielsen SW, Nebdal Svendsen V (1991) Ageing of Norwegian concrete dams with emphasis on alkali-aggregate reactions. In: Dixseptieme Congres des Grand Barages, Wien, pp 637-656.

De Corte F (1987) The $k_{0}$-standardization method. Habilitation thesis, Rijksuniversiteit Gent.

DeHills SM, Corvalán J (1964) Undulatory extinction in quartz grains of some Chilean granitic rocks of different ages. Geol Soc Am Bull 75:363-366

Denisov AV, Dubrovsky VB, Solovyov VN (2012) Radiation resistance of mineral and polymer construction materials. MEI Publishing House, Moscow, p 319

Dickinson WR (1985) Interpreting provenance relations from detrital modes of sandstone. In: Zuffa GG (ed) Provenance of Arenites. D. Reidel Publication Company, pp 331-361.

DIN EN 932 (1996) Test for general properties of aggregates - part 1: methods for sampling. DIN-adopted European Standard.

DIN EN 933 (2015) Tests for geometrical properties of aggregates. DIN-adopted European Standard.

Dolar-Mantuani L (1983) Handbook of concrete aggregates. Noyes Publications, Park Ridge, New Jersey

Drolet C, Duchesne J, Fournier B (2017) Effect of alkali release by aggregates on alkali-silica reaction. Construction and Building Materials 157:263-276.

Dron R, Brivot F (1992) Thermodynamic and kinetic approach to the alkalisilica reaction: Part I. Concepts. Cem Conc Res 22:941-948

Dron R, Brivot F (1993) Thermodynamic and kinetic approach to the alkali-silica reaction: Part II. Experiments. Cem Conc Res 23:93-103

Er S, Tuğrul A (2016) Estimation of Cerchar abrasivity index of granitic rocks in Turkey by geological properties using regression analysis. Bull Eng Geol Environ 75:1325-1339

Erdélyi M (1967) A Duna-Tisza közének vízföldtana. Hidrológiai Közlöny 47(331-340):357-365

Erichsen E, Ulvik A, Sævik K (2011) Mechanical degradation of aggregate by the Los Angeles-, the micro-Deval- and the Nordic test methods. Rock Mech Rock Eng 44:333-337

European Standard (2003) EN 1097-1 - tests for mechanical and physical properties of aggregates. Part 1: Determination of the resistance to wear (micro-Deval).

European Standard (2005) EN 1097-9-tests for mechanical and physical properties of aggregates. Part 9-Determination of the resistance to wear by abrasion from studded tyres. Nordic test.

European Standard (2006) EN 1097-2 - tests for mechanical and physical properties of aggregates. Part 2: methods for the determination of resistance to fragmentation.

EN 1367-1:2007 (2007) Tests for thermal and weathering properties of aggregates. Part 1: Determination of resistance to freezing and thawing.

EN 1367-2:2010 (2010) Tests for thermal and weathering properties of aggregates. Part 2: Magnesium sulfate test.

Fernandes I, Broekmans MATM (2013) Alkali-silica reactions: an overview. Part I. Metallogr Microstruct Anal 2(4):257-267

Fernandes I, dos Anjos Ribeiro M, Broekmans MATM, Sims I (2016) Petrographic atlas: characterisation of aggregates regarding potential reactivity to alkalis. RILEM TC 219 -ACS recommended guidance AAR-1.2, for use with the RILEM AAR-1.1 petrographic examination method. Springer, New York.

Fernandes I, dos Anjos Ribeiro M, Török Á (2018) Study of Hungarian rocks regarding potential reactivity to alkalis. In: Shakoor A, Cato K (eds) IAEG/AEG Annual Meeting Proceedings, San Francisco, California, Springer, Vol. 3, pp 91-94.
Firestone RB, Abusaleem K, Basunia MS et al (2014) EGAF: measurement and analysis of gamma-ray cross sections. Nucl Data Sheets. 119:79-87

Fleet WF (1926) Petrological notes on the Old Red Sandstone of the West Midlands. Geol Mag 63:505-516

Fournier B, Bérubé MA (2000) Alkali-aggregate reaction in concrete: a review of basic concepts and engineering implications. Can J Civ Eng 27:167-191

Franyó F (1967) A negyedkori rétegek vastagsága a Kisalföldön. MÁFI Évi Jelentése 1965-rôl 443-458.

French W (1991) Concrete petrography: a review. Quart J Engin Geol Hydrogeol 24:17-48

Galehouse JS (1969) Counting grain mounts: number percentage vs. number frequency. J Sed Res 39(2):812-815.

Gökalp İ, Uz VE, Saltan M (2016) Testing the abrasion resistance of aggregates including by-products by using Micro Deval apparatus with different standard test methods. Const Build Mat 123:1-7

Hagelia P, Fernandes I (2012) On the AAR susceptibility of granitic and quartzitic aggregates in view of petrographic characteristics and accelerated testing. In: Drimalas T, Ideker J, Fournier B (eds) Proceedings of the 14th International Conference on Alkali-Aggregate Reactions in Concrete, Austin, p 10.

Hajósy A, Sharek P, Tóth L, Gy Tóth (1993) A Szigetköz földtani kutatásai. Magyar Geofizika 34(2):86-93

Hefer A, Little D (2005) Adhesion in bitumen-aggregate systems and quantification of the effects of water on the adhesive bond. Research Report ICAR-505-1.

Hobbs DW (1988) Alkali-silica reaction in concrete. Thomas Telford, London

Hofer V, Bach H, Latal C, Neubauer A-C (2013) Impact of geometric and petrographic characteristics on the variability of LA test values for railway ballast. Math Geosci 45:727-752

$\mathrm{Hu}$ J, Stroeven P (2006) Proper characterization of pore size distribution in cementitious materials. Key Engin Mat 302-303:479-485

Ichikawa T, Koizumi H (2002) Possibility of radiation-induced degradation of concrete by alkali-silica reaction of aggregates. J Nucl Sci Tech 39(8):880-884. https://doi.org/10.1080/18811248.2002.9715272

Ichikawa T, Koizumi H (2007) Effect of nuclear radiation on alkali-silca reaction of concrete. J Nucl Sci Techn 44(10):1281-1284

Islam MA, Mahmud S, Hossain SM, Latif SA, Ahsan MH (2016) Elemental analysis of raw materials of nuclear reactor shielding to develop low activation concrete. J Nucl Sci 3(1):7-14

Jánossy D, Krolopp E (1994) Alsó-pleisztocén Mollusca- és gerinces fauna a győrújfalui kavicsbányából. Földtani Közlöny 124:403-440

Jaskó S (1990) A Duna-völgy neotektonikájának építésföldtani és környezetvédelmi vonatkozásai. [Construction-geological and environmental protectional aspects of the neotectonics of the Danube valley.] Földtani Kutatás 33(4):45-59.

Johansson E, Miškovský K, Bergknut M, Śachlová Š (2015) Petrographic characteristics of intrusive rocks as an evaluation tool of their technical properties. Geol Soc, Special Publications, London 416:217-227

Jones DR (1993) SHRP materials reference library: asphalt cements: a concise data compilation. Vol. 1, strategic highway research program, National Research Council, Washington, D.C.

Józsa S, Gy Szakmány, Miklós DG, Varga A (2020) A törmelékes üledékek és kőzetek petrográfiai vizsgálati eredményei a KárpátPannon térség kutatásában: a magyar kutatók hozzájárulása az elmúlt 150 évben. Földtani Közlöny 150(2):291-314

Kaiser M, Krolopp E, Scharek P (1998) Adatok a Duna-hordalékkúp és teraszok kapcsolatához Győr környékén. [New data on the relationship between the Danube's alluvial fan and terraces in the vicinity of Győr, Hungary. in Hungarian] Földtani Közlöny 128(2-3):519-530. 
Karátson D, Márton E, Sz Harangi, Józsa S, Balogh K, Pécskay Z, Kovácsvölgyi S, Gy Szakmány, Dulai A (2000) Volcanic evolution and stratigraphy of the Miocene Börzsöny Mountains, Hungary: an integrated study. Geologica Carpathica 51(1):325-343

Karátson D, Oláh I, Pécskay Z, Márton E, Sz Harangi, Dulai A, Zelenka T, Sz Kósik (2007) Miocene volcanism in the Visegrád Mountains (Hungary): an integrated approach to regional volcanic stratigraphy. Geologica Carpathica 58(6):541-563

Károlyi Z (1957) A Felső-Duna feltöltődő szakaszán észlelhető kavicslerakódás mennyiségének meghatározása. Vízügyi Közlöny 3:169-190

Katayama T (2004) How to identify carbonate rock reactions in concrete. Mat Charact 53(2):85-104

Katayama T (2010a) The so-called alkali-carbonate reaction (ACR) - its mineralogical and geochemical details, with special reference to ASR. Cem Concr Res 40(4):643-675

Katayama T (2010b) Diagnosis of alkali-aggregate reaction - polarizing microscopy and SEMEDS analysis. Proceedings of the $6^{\text {th }}$ International Conference on Concrete under Severe Conditions (CONSEC'10), Merida, Mexico (1), 19-34.

Katayama T, St John DA, Futagawa T (1989) The petrographic comparison of rocks from Japan and New Zealand-potential reactivity related to interstitial glass and silica minerals. In: Okada, K, Nishibayashi, S and Kawamura, M (eds) Proceedings of the $8^{\text {th }}$ International Conference on Alkali-Aggregate Reaction in Concrete (ICAAR). Kyoto, Japan: 537-542.

Kerrick D, Hooton R (1992) ASR of concrete aggregate quarried from a fault zone: results and petrographic interpretation of accelerated mortar bar tests. Cem Concr Res 22:949-960

Korkanç M, Tuğrul A (2005) Evaluation of selected basalts from the point of alkali-silica reactivity. Cem Concr Res 35:505-512

Kriván P (1960) A Duna ártéri színlőinek kronológiája. MÁFl Évi Jelentése 1960-ról 56-71.

Krutilová K, Přikryl R (2017) Relationship between polished stone value (PSV) and Nordic abrasion value (AN) of volcanic rocks. Bull Eng Geol Environ 76:85-99

Kuchařová A, Götze J, Šachlová S, Pertold Z, Přikryl R (2016) Microscopy and cathodoluminescence spectroscopy characterization of quartz exhibiting different alkali-silica reaction potential. Microsc Microanal 22:189-198

Li L, Xiong XL, Liu XC (2017) Nb/Ta fractionation by amphibole in hydrous basaltic systems: implications for arc magma evolution and continental crust formation. J Petrol 58(1):3-28

Lihou JC, Mange-Rajetzky MA (1996) Provenance of the Sardona Flysch, eastern Swiss Alps: example of high-resolution heavy mineral analysis applied to an ultrastable assemblage. Sed Geol 105:141-157

Lindsey DA, Langer WH, Vangosen BS (2007) Using pebble lithology and roundness to interpret gravel provenance in piedmont fluvial systems of the Rocky Mountains, USA. Sed Geol 199:223-232

LNEC E 415 (1993) Inertes para argamassas e betões - determinação da reactividade potencial com os álcalis. Análise petrográfica. Especificação LNEC, Lisboa, Portugal.

Lyne ÅL, Krivosheeva O, Birgisson B (2013) Adhesion between bitumen and aggregate: implementation of spectroscopic ellipsometry characterization and estimation of hamaker's constant. Mat Struct 46(10):1737-1745

Marinoni N, Voltolini M, Mancini L, Cella F (2012) Influence of aggregate mineralogy on alkali-silica reaction studied by X-ray powder diffraction and imaging techniques. J Mater Sci 47:2845-2855

McLennan SM (2001) Relationships between the trace element composition of sedimentary rocks and upper continental crust. Geochemistry, Geophysics, Geosystems 2, 2000 GC000109.

Medeiros S, Fernandes I, Fournier B, Nunes JC, Ramos V (2020) Hawaiian and Azorean volcanic aggregates: a preliminary study of the potential alkali-silica reaction. Bull Eng Geol Environ. https://doi.org/10.1007/s10064-019-01702-z

Meyer M, John T, Brandt S, Klemd R (2011) Trace element composition of rutile and the application of Zr-in-rutile thermometry to UHT metamorphism (Epupa Complex, NW Namibia). Lithos 126(3-4):388-401

Miller CM (2010) Adhesion and the surface energy components of natural minerals and aggregates. PhD dissertation, Texas A\&M University.

Miller C, Vasconcelos K, Little D, Bhasin A (2011) Investigating aspects of aggregate properties that influence asphalt mixtures performance. Research report for DTFH61-06-C-00021, Texas A\&M University at College Station and The University of Texas at Austin, Texas.

Molnár GL (2004) Handbook of prompt gamma activation analysis. Kluwer Academic Publishers, Dordrecht

Molnár P (1995) Dunai terasz-fejlődési modell. Unpublished manuscript, MÁFI Database.

Monnin Y, Dégrugilliers P, Bulteel D, Garcia-Diaz E (2006) Petrography study of two silicaeous limestones submitted to alkali-silica reaction. Cem Concr Res 36(8):1460-1466

Neville A (1997) Aggregate bond and modulus of elasticity of concrete. ACI Materials J 94(1):71-74

Pang L, Wu S, Zhu J, Wan L (2010) Relationship between petrographical and physical properties of aggregates. J Wuhan Univ Technol Mater Sci 25(4):678-681

Parker RL, Fleischer M (1968) Geochemistry of niobium and tantalum. Geological Survey Professional Paper 612, United States Government Printing Office, Washingon, 43 p.

Passchier CW, Trouw RAJ (2005) Microtectonics, 2nd edn. Springer, Berlin

Pécsi M (1959) A magyarországi Dunavölgy kialakulása és felszínalaktana. Akadémiai Publisher, Budapest

Pécsi M (1962) A Kisalföld geomorfológiai képe. Földrajzi Közlemények X(LXXXVI):113-140.

Pécsiné Donáth É (1958) Duna-terasz kavicsok görgetettségi vizsgálata. [Investigations on the roundness of Danube terrace gravels.] Földtani Közlöny 88:57-75.

Pettijohn FJ, Potter PE, Siever R (1987) Sand and sandstone. SpringerVerlag, Berlin

Pignatelli I, Kumar A, Field KG, Wang B, Yu Y, Le Pape Y, Bauchy M, Sant G (2016) Reactivity alterations of minerals following irradiation: the case of calcite and quartz. Scientific Reports 6:20155

Ramachandran VS, Beaudoin JJ (2000) Handbook of analytical techniques in concrete science and technology: principles, techniques and applications. Elsevier

Ramos V, Fernandes I, Noronha F, Santos Silva A (2011) Petrographic characterization of granitic aggregates. Comparison with the results from laboratory tests. In: Proceedings of the 13th Euroseminar on Microscopy Applied to Building Material, p 10.

Ramos V, Fernandes I, Santos Silva A, Soares D, Fournier B, Leal S, Noronha F (2016) Assessment of the potential reactivity of granitic rocks-petrography and expansion tests. Cem Concr Res 86:63-77

Ranjbar S, Tabatabaei Manesh SM, Mackizadeh MA, Tabatabaei SH, Parfenova OV (2016) Geochemistry of major and rare earth elements in garnet of the Kal-e Kafi skarn, Anarak Area, Central Iran: Constraints on processes in a hydrothermal system. Geochem Int 54:423-438

Rayment PL, Pettifer K, Hardcastle J (1990) The alkali-silica reactivity of British concreting sands, gravels and volcanic rocks. Contractor Report 218, Transport and Road Research Laboratory, Crowthorne, UK.

Rigopoulos I, Tsikouras B, Pomonis P, Hatzipanagiotou K (2013) Determination of the interrelations between the engineering parameters of construction aggregates from ophiolite complexes of Greece using factor analysis. Con Build Mat 49:747-757 
RILEM Recommended Test Method: AAR-1.1 (2016) —Detection of potential alkali-reactivity-part 1: petrographic examination method. In: Nixon PJ, Sims I (eds) RILEM recommendations for the prevention of damage by alkali-aggregate reactions in new concrete structures.

RILEM Recommended Test Method: AAR-2 (2016) —Detection of potential alkali-reactivity - accelerated mortar-bar test method for aggregates. In: In: Nixon PJ, Sims I (eds) RILEM recommendations for the prevention of damage by alkali-aggregate reactions in new concrete structures.

Révay ZS (2009) Determining elemental composition using prompt $\gamma$ activation analysis. Anal Chem 81:6851-6859

Rosseel TM, Maruyama I, Le Pape Y, Kontani O, Giorla AB, Remec I, Wall JJ, Sircar M, Andrade C, Ordonez M (2016) Review of the current state of knowledge on the effects of radiation on concrete. J Adv Conc Techn 14:368-383

Šachlová S, Kuchařová A, Pertold Z, Přikryl R, Fridrichová M (2017) Quantitative assessment of alkali silica reaction potential of quartz-rich aggregates: comparison of chemical test and accelerated mortar bar test improved by SEM-PIA. Bull Eng Geol Env 76(1):133-144

Šachlová S, Kuchařová A, Pertold Z, Přikryl R (2016) Evaluation of alkali-silica reaction potential of quartz-rich rocks by alkaline etching of polished rock sections. Env Earth Sci 75:730

Sajid M, Arif M (2015) Reliance of physico-mechanical properties on petrographic characteristics: consequences from the study of Utla granites, north-west Pakistan. Bull Eng Geol Environ 74:1321-1330

Saouma V, Hariri-Ardebili MA (2014) A proposed aging management program for alkali silica reactions in a nuclear power plant. Nucl Engin Design 277:248-264

Sengul O, Tasdemir C, Tasdemir M (2002) Influence of aggregate type of mechanical behavior of normal- and high-strength concretes. ACI Materials J 99(6):528-533

Shannon J, Howard I, Cost V, Wilson W (2015) Benefits of Portlandlimestone cement for concrete with round gravel aggregates and higher fly ash replacement rates. In: TRB 94th Annual Meeting Compendium of Papers, Report 15-4049, p 17.

Shannon J, Howard I, Cost V (2017) Potential of Portland-limestone cement to improve performance of concrete made with high slag cement and fly ash replacement rates. ASTM Journal of Testing and Evaluation 45(3):1-17

Shimizu N (1975) Rare earth elements in garnets and clinopyroxenes from garnet lherzolite nodules in kimberlites. Earth Plan Sci Let 25(1):26-32

Smith MP, Henderson P, Jeffries TER, Long J, Williams CT (2004) The Rare Earth elements and uranium in garnets from the Beinn an Dubhaich Aureole, Skye, Scotland, UK: constraints on processes in a dynamic hydrothermal system. J Petrol 45(3):457-484

Stanton T (1940) Expansion of concrete through reaction between cement and aggregate. Proc. of ASCE 66:1781-1811

Stipp M, Stünitz H, Heilbronner R, Schmid SM (2002) The eastern Tonale fault zone: a 'natural laboratory' for crystal plastic deformation of quartz over a temperature range from 250 to $700{ }^{\circ} \mathrm{C}$. $\mathrm{J}$ Struct Geol 24:1861-1884

Sümeghy J (1952) Földtani adatok a Duna-Tisza köze északi részéről. MÁFl Évi Jelentése 1948-ról 85-99.

Sümeghy J (1953) A Duna-Tisza közének földtani vázlata. MÁFI Évi Jelentése 1950-rôl 233-264.
Swamy RN (1992) The alkali-silica reaction in concrete. Glasgow; London/New York, NY: Blackie/Van Nostrand Reinhold.

Szádeczky-Kardoss E (1938) Geologie der rumpfungarländischen Kleinen Tiefebene. Mitteilungen der berg- und hüttenmännischen Abteilung an der P.-J. Universität Sopron.

Szeberényi J, Józsa S, Medved'ová A, Holec J, Balogh J, Fábián SÁ, Kis É, Varga Gy, Viczián I (2014) Dunateraszok helyzete a Visegrádiszorosban. In: Kóródi T, Sansumné Molnár J, Siskáné Szilasi B, Dobos E (eds.), Proceedings of the $7^{\text {th }}$ Hungarian Geographical Conference, Miskolc University, Miskolc, Hungary, ISBN 978963-358-063-9, 513-527.

Szentmiklósi L, Párkányi D, Sziklai-László I (2016) Upgrade of the Budapest neutron activation analysis laboratory. J Radioanal Nucl Chem 309(1):91-99

Szentmiklósi L, Belgya T, Zs Révay, Kis Z (2010) Upgrade of the prompt gamma activation analysis and the neutron-induced prompt gamma spectroscopy facilities at the Budapest research reactor. J Radioanal Nucl Chem 286:501-505

Szilágyi V, Gméling K, Kis Z, Harsányi I, Szentmiklósi L (2019) Neutron-based methods for the development of concrete. In: Glinicki MA, Jóźwiak-Niedźwiedzka D, Leung ChKY, Olek J (eds) Monograph Brittle Matrix Composites BMC-12, pp 183-194, ISBN 978-83-65550-20-0.

Taylor SR, McLennan SM (1985) The continental crust; its composition and evolution; an examination of the geochemical record preserved in sedimentary rocks. Blackwell, Oxford

Thamóné Bozsó E (2002) Magyarországi kainozoos homokok és homokkövek ásványi alkotói és származásuk meghatározásának lehetősége. A Magyar Állami Földtani Intézet Évi Jelentése 19971998-ról: 119-134.

Török Á, Czinder B (2017) Relationship between density, compressive strength, tensile strength and aggregate properties of andesites from Hungary. Environ Earth Sci 76:639

Wang W, Cheng Y, Tan G, Tao J (2018) Analysis of aggregate morphological characteristics for viscoelastic properties of asphalt mixes using simplex lattice design. Materials 11:1908. https://doi.org/ 10.3390/ma11101908

Warren CJ, Greenwood LV, Argles TW, Roberts NMW, Parrish RR, Harris NBW (2018) Garnet-monazite rare earth element relationships in sub-solidus metapelites: a case study from Bhutan. Geological Society, London, Special Publications 478:145-166

Wenk H-R, Monteiro PJM, Shomglin K (2008) Relationship between aggregate microstructure and mortar expansion. A case study of deformed granitic rocks from the Santa Rosa mylonite zone. J Mater Sci 43(4):1278-1285.

Wenk M, Tutumluer E, Moaveni M, Gehringer E (2013) Investigation of aggregate properties influencing railroad ballast performance. Transportation Research Record: Journal of the Transportation Research Board 2013:180-189

West G (1991) A note on undulatory extinction of quartz in granite. Engin Geol 24:159-165

West G (1994) Undulatory extinction of quartz in some British granites in relation to age and potential reactivity. Quart J Engin Geol 27:69-74

Wigum BJ (1995) Examination of microstructural features of Norwegian cataclastic rocks and their use for predicting alkalireactivity in concrete. Eng Geol 40(3-4):195-214 